\title{
Targeting Oncogenic Transcriptional Networks in Neuroblastoma: From N-Myc to Epigenetic Drugs
}

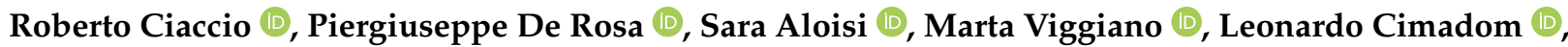 \\ Suleman Khan Zadran $\mathbb{E}$, Giovanni Perini ${ }^{+}$and Giorgio Milazzo ${ }^{*}+\mathbb{E}_{\mathbb{E}}$
}

Citation: Ciaccio, R.; De Rosa, P.; Aloisi, S.; Viggiano, M.; Cimadom, L.; Zadran, S.K.; Perini, G.; Milazzo, G. Targeting Oncogenic Transcriptional Networks in Neuroblastoma: From $\mathrm{N}-\mathrm{Myc}$ to Epigenetic Drugs. Int. J. Mol. Sci. 2021, 22, 12883. https:/ / doi.org/10.3390/ijms222312883

Academic Editor: Francisco M. Vega

Received: 5 November 2021

Accepted: 26 November 2021

Published: 28 November 2021

Publisher's Note: MDPI stays neutral with regard to jurisdictional claims in published maps and institutional affiliations.

Copyright: (c) 2021 by the authors. Licensee MDPI, Basel, Switzerland. This article is an open access article distributed under the terms and conditions of the Creative Commons Attribution (CC BY) license (https:// creativecommons.org/licenses/by/ $4.0 /)$.
Department of Pharmacy and Biotechnology, University of Bologna, 40126 Bologna, Italy; roberto.ciaccio2@unibo.it (R.C.); piergiuseppe.derosa2@unibo.it (P.D.R.); sara.aloisi4@unibo.it (S.A.); marta.viggiano2@unibo.it (M.V.); leonardo.cimadom@studio.unibo.it (L.C.); sulemankhan.zadran@unibo.it (S.K.Z.); giovanni.perini@unibo.it (G.P.)

* Correspondence: giorgio.milazzo@unibo.it

+ These authors contributed equally to this work.

\begin{abstract}
Neuroblastoma (NB) is one of the most frequently occurring neurogenic extracranial solid cancers in childhood and infancy. Over the years, many pieces of evidence suggested that NB development is controlled by gene expression dysregulation. These unleashed programs that outline NB cancer cells make them highly dependent on specific tuning of gene expression, which can act co-operatively to define the differentiation state, cell identity, and specialized functions. The peculiar regulation is mainly caused by genetic and epigenetic alterations, resulting in the dependency on a small set of key master transcriptional regulators as the convergence point of multiple signalling pathways. In this review, we provide a comprehensive blueprint of transcriptional regulation bearing NB initiation and progression, unveiling the complexity of novel oncogenic and tumour suppressive regulatory networks of this pathology. Furthermore, we underline the significance of multi-target therapies against these hallmarks, showing how novel approaches, together with chemotherapy, surgery, or radiotherapy, can have substantial antineoplastic effects, disrupting a wide variety of tumorigenic pathways through combinations of different treatments.
\end{abstract}

Keywords: neuroblastoma; oncogene; tumour suppressor; regulatory network; gene expression; MYCN; CRC; HDACi; GD2; epigenetic therapies

\section{Neuroblastoma: An Overview}

Childhood and paediatric cancers are among the most relevant causes of death that affect children during the first years of life. Although researchers took into consideration several risk factors that can determine cancer development in children and adolescents, their causes are mostly unknown. Moreover, the absence of recommended screening tests able to define tumour formation and evolution was complicated by methodological difficulties related to the biological variety of these diseases, all contributing to the poor pathology outcome. Nevertheless, progresses of new high-throughput sequencing techniques and the application of genome-wide analyses made it possible to better understand the genetic backgrounds of many paediatric cancers, which influences their initiation and evolution. In this context, neuroblastoma (NB) is a clear example of how altered gene expression affects the dysregulation of crucial cellular mechanisms, such as proliferation, differentiation, chromosome stability, and self-renewal [1]. Remarkably, NB is considered the most common extracranial solid tumour identified in infancy, with 25-50 cases per million individuals. It is the first cause of death for children between one and five years of age, representing $13 \%$ of overall paediatric cancers. This neuroendocrine tumour arises in the developing sympathetic nervous system, the fallout of which is tumour development localized both in the adrenal glands and sympathetic ganglia, and it differs from other solid tumours by 
its biological and clinical heterogeneity, spanning from spontaneous regression to overly aggressive metastatic diseases [1].

The cellular origin of NB is not precisely identified yet; therefore, the observed clinical diversification of NB is ascribed to the disruption of the meticulously arranged process of neural crest maturation through the connection of many molecular components at various stages. The broad spectrum of NB clinical behaviour describes a challenging goal for diagnosis, prognosis, and selection of the most fruitful treatment strategy-moreover, its obstacles compare clinical trials between different studies. In 1988, an international congress was held to elaborate a system intended to help the clinical trial procedures. The result was the International NB Staging System (INSS), according to which NB can be classified into five distinct stages [2]. Stage 1 and stage $2 \mathrm{NB}$, considered low-risk tumours ( $>90 \%$ survival rate), are relatively small, specifically localized, not metastatic and can be entirely removed by surgery; however, stage $2 \mathrm{NB}$ could be persistent after surgery, requiring further treatment with chemotherapy and/or irradiation. Stage $3 \mathrm{NB}$ is an intermediate/high-risk tumour (30-50\% survival rate), with metastatic infiltration in lymph nodes nearby the original onset site but not in distant parts of the body. The more aggressive Stage 4 is the high-risk tumour ( $<30 \%$ survival rate), with metastases spread through distinct parts of the body, including lymph nodes, liver, skin, and bone marrow. The fifth stage, $4 \mathrm{~S}$, is significantly different from the earlier classes; it can initially manifest typical aggressive tumours, but then it undergoes spontaneous regression with minimum treatment, or even without medical intervention (average survival rate 50-80\%). This tumour is usually diagnosed via standard histology analysis and detection of unusual urinary catecholamines. At the same time, the five stages are recognized according to a series of features that include the age of diagnosis, MYCN gene amplification status, histology, and localisation of eventual metastases [2]. More than $50 \%$ of all patients are diagnosed with either stage 3 or stage 4 NB that may yield various tumour phenotypes [3]. This incredible tumour variability well reflects the genetic heterogeneity typical of this condition.

\section{Genetic Predisposition and Chromosome Instability in NB}

To date, no single genetic lesions are known to account for all NB patients. These data support the idea of NB as a spectrum of diseases rather than a single pathological condition. Nonetheless, some genetic alterations and oncogenic drivers have diagnostic and prognostic significance in specific stratification groups (Table 1) [4,5]. Although the aetiology of this disease is still not fully understood, NB can be classified as either sporadic or familial, depending on whether the mutation occurred in the patient. Indeed, the NGS (next generation sequencing) revolution has led to a deeper understanding of the NB genomic landscape. These novel approaches shed light on several aberrations already involved in the tumorigenesis and revealed new ones, spanning from gains and deletions of entire chromosomes to segmental chromosome alterations and single-nucleotide mutations. The first identified familial gene for NB was PHOX2B, whose mutations predispose to disease development in $\sim 10 \%$ of familial cases. It encodes a master regulator transcription factor (master TF), playing a pivotal role in early embryogenesis for autonomic nervous system development [6-8]. Consequently, mutations in this gene are associated with a spectrum of pathological phenotypes. PHOX2B NB-specific mutations are gain-of-function, missense, and frameshift variants, mapping at 200-300 bp and 600-714 bp from the ATG start codon [9].

Despite PHOX2B, the anaplastic lymphoma kinase (ALK) gene is considered the major susceptibility gene for familial NB and the most often mutated gene in sporadic cases. ALK encodes a transmembrane receptor tyrosine kinase involved in nervous system development. It acts as an oncogene for several human tumours (such as several types of lymphoma and non-small cell lung cancer), mainly activated by chromosomal rearrangements resulting in fusion genes. Differently, the most frequent ALK alterations in NB are both sequence mutations, involving the tyrosine kinase protein domain and causing constitutive ALK activation and kinase activity, and copy number alterations, 
given by trisomy $2 p$ and gene amplification $[10,11]$. ALK can also be affected more rarely by structural alterations resulting in $\mathrm{N}$-terminal deletions, leading to a truncated isoform being constitutively activated and supporting oncogenic properties [12-14].

However, familial cases of NB account for only $1-2 \%$ of cases and the majority of NB are the sporadic ones. The most common and most clearly implicated genomic alteration is the MYCN gene amplification, which is present in $~ 18 \%$ of cases, considering WGS or WES data of 1232 NB samples from two different studies combined with data generated by the Therapeutically Applicable Research to Generate Effective Treatment initiative (TARGET, https:/ / ocg.cancer.gov/programs/target_phs000467 (accessed on 21 June 2021 via cBio Portal for Cancer Genomic https://www.cbioportal.org/)) [15,16]. MYCN focal gain is a well-established prognostic factor for high-risk cases, marked by advanced tumour stage, high aggressiveness, and poor outcome. The origin of MYCN amplification is still unclear, but it is considered an initiating event for tumorigenesis in high-risk cases, conferring stem-like properties to MYCN amplified cells [17-19]. Approximately $70 \%$ of NB patients with MYCN amplification show loss of heterozygosity ( $\mathrm{LOH}$ ) at 1p36, a segmental chromosomal alteration common to different human cancers, especially the ones affecting the nervous system. The hypothesis is that this region holds several gene-dosage-sensitive tumour suppressor genes co-operating with driver mutations for oncogenesis. Regarding $\mathrm{NB}, 1 \mathrm{p} 36$ deletion is the most common genomic lesion in high-risk cases. Its role in tumorigenesis has been explained by in vitro studies in mouse-derived cell models, which revealed $1 \mathrm{p} 36 \mathrm{LOH}$ could achieve neoplastic transformation collaborating with other alterations or encourage MYCN amplification, depending on deletion sizes. Moreover, two tumour suppressor genes have been revealed. CHD5 has been proposed as a distal tumour suppressor, involved in smaller 1p36 deletions associated with MYCN single-copy NB and MYCN-amplified NB. Otherwise, ARID1A acts as a proximal tumour suppressor, promoting tumorigenesis via MYCN amplification in tumours harbouring larger 1p36 deletions [20]. ARID1A encodes a factor belonging to the SWI/SNF complexes and regulates gene expression through chromatin structure modulation. ARID1A depletion supports the adrenergic-to-mesenchymal transition by regulating enhancer-mediated gene expression, thus promoting cell invasion and tumour resistance to chemotherapy [21].

Other frequent structural variants in NB are $17 \mathrm{q}$ gain and $11 \mathrm{q}$ deletion. Gain of the long arm of chromosome $17(17 \mathrm{q})$ is the most common chromosomal rearrangement in NB, considered a characteristic sign of high-risk cases, in association with MYCN amplification and $1 p$ deletion [22]. The hypothesis for the increased aggressiveness of $17 q$ gain NB is that 17q gain itself could enhance genomic instability, increasing tumour cell mutational burden. Particularly, the resulting overexpression of several electron transport chain genes mapping at the $17 \mathrm{q}$ locus would lead to an increase in ROS production and, so, improve tumour genetic alterations, intensifying tumour aggressiveness [14]. Several genes have been proposed as $17 q$ oncogenes, but further analysis is needed to better define $17 q$ oncogene contribution to NB. JMDJ6 gene has been identified as an NB tumorigenesis factor, inducing reduction in NB cell proliferation and survival in vitro and tumour progression in mice when it is knocked down [23]. Using both whole-genome and RNA sequencing data, prohibiting gene (PHB) is highly expressed in 17q gain NB, enhancing tumour cell proliferation and suppressing differentiation with a novel mechanism [24]. Increased NME1 gene expression has also been associated with high-risk NB, suggesting a potential role of histidine kinase signalling in tumour pathogenesis [25]. Moreover, ALYREF gene has been proposed as a codriver factor for oncogenesis in NB by in vitro and in vivo transgenic models, co-operating with N-Myc for USP3 transcription upregulation, and thus regulating MYCN turnover [26]. However, a better definition of these genes' involvement is still to be determined. 11q deletion is the segmental chromosomal alteration most often associated with other genomic alterations in high-risk NB, and the most identified following MYCN amplification and 17q gain. MYCN amplification and 11q deletion co-occurrence are sporadic; $11 \mathrm{q}$ deletion has been shown to be associated with large $2 \mathrm{p}$ gain, including MYCN and other genes, such as ALK [27]. This inverse correlation between deletion of 11q 
locus and MYCN focal gain could be due to their common effect in NB pathogenesis: both can disrupt microRNA let-7, which is considered to possess a fundamental role in tumour development. 11q deletion could be the missing aberration to acquire in order to reach the threshold for let-7 disruption in a context of insufficient MYCN copy number [28]. 11q deletion tumours are characterised by older diagnosis, more advanced disease stages, and a higher risk of relapse. Several genes involved in DNA repair mechanisms map at this locus, such as TSLC1, ATM, and H2AFX. Their missing activity caused by haploinsufficiency or inactivation of the second allele by other mutational events could explain the high chromosomal instability marking $11 \mathrm{q}$ del NB and the higher relapse probability and worse prognosis [27]. Chromosome 11 is also involved in other NB-relevant chromosomal rearrangements, such as translocation involving chromosome 11 and $17(\mathrm{t}(11 ; 17))$ and disrupting SHANK2 gene. SHANK2 is a neurodevelopmental gene encoding a scaffold protein in the postsynaptic density and was recently identified as a new tumour suppressor gene in NB. Indeed, among genes recurrently disrupted by structural variants in NB, a strong enrichment in neurodevelopmental disorders (NDDs) genes has been found, in addition to their downregulation in high-risk NB cases. Among them, SHANK2 showed the most reduced expression, and it has been proposed that its deregulation can promote NB cell dedifferentiation and poor survival. Moreover, other autism spectrum disorder (ASD) and synaptic genes, such as DLG2 (also mapping at 11q locus and frequently disrupted by translocation events in NB), have been proposed as candidate genes with a similar role in NB pathogenicity. In contrast, germline mutations associated with NDDs have been found to confer an increased risk of developing the tumour [29]. Therefore, neurodevelopmental processes seem to have a key role in NB tumorigenesis, and further investigations on these genes need to be performed.

Most NB cancer cells also show genomic alterations resulting in the activation of telomeres maintenance mechanisms, allowing tumour cells infinite proliferation and survival, consisting of the upregulation of telomerase activity or the activation of the ALT pathway. Elevated telomerase activity is associated with high-risk NB and can be due to both MYCN amplification and TERT gene rearrangements, which occur, respectively, in $40 \%$ and $20 \%$ of high-risk NB. Rearrangements in TERT upstream and downstream regions would cause TERT overexpression by genomic repositioning, acting as potent cancer driver mutations $[15,30]$. Instead, ALT pathway activation is principally caused by ATRX mutations, usually age-correlated, and occurs in patients older than 18 months [31]. ALT is a telomeres maintenance machinery based on homologous recombination and telomerase independence. ATRX protein belongs to a polyprotein complex involved in chromatin remodelling, nucleosome assembly, and telomeres maintenance. Loss-of-function mutations in ATRX lead to defective H3.3 deposition and replicative forks stall at the telomeric regions, inducing ALT activation for telomeres elongation. Furthermore, the second mechanism of contribution to tumorigenesis has been shown for ARTX: defective H3.3 deposition in other genomic regions, such as promoter and enhancer regions of neuronal differentiation genes, would cause their attenuated expression and proliferation of cancer cells [32].

In addition to the above-mentioned and well-known segmental chromosomal alterations, other structural variants have also been identified in NB cases, such as $3 p$ and $4 p$ deletions and $1 q$ gain. However, they are relatively more rare alterations whose role has still to be clarified. Similarly, the implication of numerical chromosomal alterations (NCA) is still not well defined. It is known that gains or losses of entire chromosomes and triploidy are associated with the absence of segmental chromosomal alterations and a favourable prognosis. For example, in a recent retrospective multi-centric study, whole chromosome 19 gain has been identified in a subgroup of samples with lower tumour stages, absence of structural variants, and better outcomes. Moreover, in a previous study, whole chromosome $\mathrm{X}$ loss has been proposed as a new prognosis marker for NCA cases. However, few specific issues have been described, and studies are needed [33]. As briefly described above, the presence of genomic alterations in NB cells seems to be nonrandomly distributed. Instead, it appears to be under a relationship of co-occurrence and mutual 
exclusion. For example, MYCN amplification, TERT gene rearrangement, and ALT pathway activation caused by ATRX mutations converge on the similar cellular result (telomere length maintenance) and are mutually exclusive $[15,30]$. Specifically, MYCN amplification and ATRX-inactivating mutations are incompatible in all stages of NB, leading to synthetic genetic lethality due to the excessive DNA-replicative stress caused by these alterations [32]. By contrast, MYCN and TERT rearrangement relationships are not clear, and there is still no consensus among data about it. In some cases, both MYCN and TERT alterations have been identified in the same samples [14]. Differently, due to their common location at 2p, ALK amplification often shows co-occurrence with MYCN amplification. Indeed, an MYCN-ALK co-operation model based on PI3K signalling has been proposed [19]. However, from a recent analysis of WGS data from 182 diagnosis samples, no statistically significant co-occurrence has been identified between ALK and other gene alterations. The same study also confirmed the mutual exclusivity relationship between MYCN alterations and other segmental chromosome aberrations, such as $\mathrm{t}(11 ; 17), 3 \mathrm{p}$ deletion, $4 \mathrm{p}$ deletion, and 11q deletion. Moreover, these data support the already known absence of correlation between $1 p$ deletion and other copy number alterations, and confirm the co-occurrence between $3 p$ deletion, $4 p$ deletion, $11 q$ deletion, $7 q$ gain, and $17 q$ gain. NB genomic alteration shows different prevalence among age: it has been proposed that the acquisition of specific oncogenic mutations could be age-correlated due to a different sensibility of developmental stage. MYCN and TERT alteration are more common in patients below five years old, while ARTX mutations are enriched in older patients. Otherwise, segmental chromosomal alteration is more common from 1.5 years old [14]. Several studies have also investigated the molecular genetic profiling of adult-onset NB, proposing that the poorer survival in an adult could be caused by the presence of different genetic alterations between paediatric and adult NB $[31,34,35]$. However, from a recent study investigating the molecular genetics of adult-onset NB, no differences have been identified in the type of genetic alterations between paediatric and adult NB, supposing that paediatric and adult NB differ in frequency and not to the kind of specific changes [36].

Table 1. Leading genetic alterations in NB.

\begin{tabular}{|c|c|c|c|c|c|c|}
\hline $\begin{array}{l}\text { Gene } \\
\text { Name }\end{array}$ & CHr. & $\begin{array}{l}\text { Alteration } \\
\text { Type }\end{array}$ & Known NB Variants & $\begin{array}{c}\text { Mutation } \\
\text { Effect }\end{array}$ & MYCN Status $^{\circ}$ & References \\
\hline \multicolumn{7}{|c|}{ Single-Gene Alterations } \\
\hline \multirow[t]{3}{*}{ ALK } & \multirow[t]{3}{*}{$2 \mathrm{p} 23$} & $\begin{array}{c}\text { Point } \\
\text { mutation } \\
\text { (missense) }\end{array}$ & $\begin{array}{c}\text { Met1166Asn; } \\
\text { Ile1171Asn/Thr; } \\
\text { Phe1174Leu/Cys/ } \\
\text { Ile/Val/Ser } \$ ; \\
\text { Leu1240Val; } \\
\text { Phe1245Ile/Cys §; } \\
\text { Arg1275Gln/Leu }\end{array}$ & \multirow[t]{3}{*}{$\begin{array}{l}\text { Gain of } \\
\text { function }\end{array}$} & $\begin{array}{c}\text { Amp + } \\
\text { non-Amp }\end{array}$ & {$[37], \#$} \\
\hline & & Amplification & - & & Amp & {$[38]$} \\
\hline & & $\begin{array}{c}\text { Translocation/ } \\
\text { Deletion }\end{array}$ & - & & - & {$[12,13]$} \\
\hline \multirow[t]{2}{*}{ ATRX } & $\mathrm{Xq} 21.1$ & $\begin{array}{c}\text { Point } \\
\text { mutation } \\
\text { (nonsense) }\end{array}$ & $\begin{array}{l}\text { Glu285 *; Glu990 *; } \\
\text { Leu1645* }\end{array}$ & \multirow[t]{2}{*}{ Loss of function } & \multirow[t]{2}{*}{ non-Amp } & \multirow[t]{2}{*}[32]{,$\#$} \\
\hline & & $\begin{array}{c}\text { Point } \\
\text { mutation } \\
\text { (frameshift } \\
\text { deletion) }\end{array}$ & Phe2113Serfs *9 & & & \\
\hline
\end{tabular}


Table 1. Cont.

\begin{tabular}{|c|c|c|c|c|c|c|}
\hline $\begin{array}{l}\text { Gene } \\
\text { Name }\end{array}$ & CHr. & $\begin{array}{c}\text { Alteration } \\
\text { Type }\end{array}$ & Known NB Variants & $\begin{array}{c}\text { Mutation } \\
\text { Effect }\end{array}$ & MYCN Status $^{\circ}$ & References \\
\hline PHOX2B & 4 p13 & $\begin{array}{c}\text { Point } \\
\text { mutation } \\
\text { (missense and } \\
\text { frameshift) }\end{array}$ & $\begin{array}{l}\text { Several variants } \\
\text { clustered at } 200-300 \\
\text { bp and } 600-714 \mathrm{bp} \\
\text { from the translation } \\
\text { start codon }\end{array}$ & $\begin{array}{l}\text { Gain of } \\
\text { function }\end{array}$ & - & [9] \\
\hline TERT & $5 p 15.33$ & $\begin{array}{l}\text { Upstream/ } \\
\text { downstream } \\
\text { regions } \\
\text { rearrangements }\end{array}$ & - & $\begin{array}{l}\text { Gain of } \\
\text { function }\end{array}$ & non-Amp & {$[15,30]$} \\
\hline \multicolumn{7}{|c|}{ Segmental Chromosomal Alterations } \\
\hline- & $1 \mathrm{p} 36$ & Deletion & - & Loss of function & Mostly amp & {$[20]$} \\
\hline- & $17 \mathrm{q}$ & Gain & - & $\begin{array}{l}\text { Gain of } \\
\text { function }\end{array}$ & Amp & [39] \\
\hline- & $11 \mathrm{q}$ & Deletion & - & Loss of function & non-Amp & [27] \\
\hline
\end{tabular}

MYCN status: Amp = presence of amplified MYCN; non-Amp = non-amplified MYCN. * indicates translation termination codon in nonsense and frameshift variants. § Amino acid residue identified as a recurrent hotspot (statistically significant) in a population-scale cohort of tumour samples of various cancer types, using methodology based in part on Chang et al. [40] and according to cancerhotspots.org. \# cBio Portal for Cancer Genomic [41,42]. NB data come from 1459 patients/1472 samples obtained by combining four different studies $[15,16,43]$ and data generated by the Therapeutically Applicable Research to Generate Effective Treatment initiative (TARGET, https: / / ocg.cancer.gov / programs / target_phs000467 (accessed on 21 June 2021 via cBio Portal for Cancer Genomic https:/ / www.cbioportal.org/)). Sequence variants are reported according to Human Genome Variation Society (HGVS).

\section{Emerging Concepts of Epigenetic Dysregulation in NB}

While most of the alterations responsible for inducing the familial NB cases have been well characterised, the same cannot be said regarding the sporadic ones, which show reduced levels of genetic alterations when sequenced [43]. This fact has shifted the attention on the epigenome: the whole asset of chemical modifications targeting DNA or histone protein tails can bear regulating gene expression throughout the genome. The epigenetic changes shape chromatin conformation, thereby easing or obstructing the binding of specific factors to specific genomic sequences. Several different actors take part in this process, and they can be roughly summarized in three classes: "writers" able to label histones with post-translational modifications, "readers" which bind specifically to the labelled chromatin regulating gene expression, and "erasers" restoring the unmodified protein [44]. The concentred action of these factors generates a specific signature that can be interpreted to gain further insight into normal development and pathological contexts. Recent chromatin immunoprecipitation (ChIP) assays coupled with high throughput sequencing revealed distinct epigenetic labelling, characterising not only subtypes of NB itself [45], but also differentiating subtypes of neural stem cells (NSCs)-derived tissues, such as neuroectoderm, neural crest, and more mature neural states, thus, stating the ability of NSCs to adopt multiple fates upon commitment [46]. The epigenome is, thereby, a cell fate indicator: an observation that can be exploited to highlight alterations within chromatin structure during mammalian development [47,48]. Malignancies usually involve both the genetic and the epigenetic landscape, with nonfamilial NB cases being an exception: the poor frequency of genomic mutations states an epigenetic-mediated alteration of the transcription's balance, leading to cancer progression via multiple ways, such as increased cell plasticity or tumour suppressor gene silencing [49].

For instance, both NSCs and embryonic stem cells (ESCs) are characterised by many genes kept transcriptionally silenced until differentiation, even though they display both permissive and repressive epigenetic marks on the relative promoters [50]. The definition of "bivalent domains" can explain this situation. Both permissive (H3K4me3) and repressive (H3K27me3) marks consent to rapidly route cells towards any fate, considering 
that genes enriched with H3K27me3 in ESCs include those involved in early embryonic development, organogenesis, and cell fate decisions. Genes needed to be transcribed lose most of their polycomb-mediated repressive H3K27 methylation. On the other hand, those maintained as silenced lose their H3K4 methylation and/or increase the polycomb-induced repressive epigenetic mark $[50,51]$. The high impact at which epigenetic regulation can influence transcriptional balance is commonly acknowledged among the scientific community. Interestingly, one of the most prominent histone methyltransferases (HMT), EZH2, a "writer" member of the polycomb repressive complex 2 (PRC2) and responsible for H3K27 trimethylation, is characterised by increased expression levels in NB [52]. In fact, several in vitro and in vivo studies reported that, in MYCN-amplified NBs, the gene promoter of EZH2 is directly regulated by N-Myc [53-55]. N-Myc can also directly interact with $\mathrm{EZH} 2$, and overexpression of EZH2 promotes an undifferentiated NB tumour phenotype associated with poor clinical outcomes $[53,56]$.

A further example of an important chromatin-regulating actor in NB biology is the histone demethylase LSD1 (KDM1A), an "eraser" factor able to demethylate H3K4me2/me1 to unmethylated H3K4, which is associated with gene silencing. A high level of LSD1 function in an NB context correlates with a bad prognosis of patients and poorly differentiated cells (in vitro assays) [57].

Transcription factors (TFs) can also recruit chromatin-remodeller-containing repressive complexes to their target loci. Above all, N-Myc can exert repressive functions interacting with the basal transcription factor 1 (SP1). This repressive complex requires the sequencespecific transcription factor MIZ-1 to bind targets' promoter regions and recruit other chromatin modifiers, such as the "eraser" histone deacetylases (HDAC) [58,59]. The most well-characterised repressive complexes that are known to have a role in NB development are the polycomb repressive complex 2 (PRC2), Sin3, nucleosome remodelling and deacetylase complex (NuRD), silencing mediator for retinoid and thyroid hormone receptors (SMRT), C-terminal binding proteins (CtBP), and REST corepressor (CoREST) complexes all sharing one or more protein of the HDAC family [60]. These complexes have been widely investigated in a cancer landscape, even though just a modest number of studies have drawn attention to their behaviour in NB and to how they differentially work in this context. Providing some examples, Gajer et al. [61] showed that inhibition of HAT activity in vitro and in vivo blocked NB cells growth; Chen et al. [54] demonstrated that knockdown of the PRC2 component EZH2 or its depletion upon inhibitor treatment resulted in markedly decreased NB cell viability; Yang et al. [62] proved that the silencing of the histone demethylase LSD1, a component of CoREST complexes, resulted in a reduction in cell proliferation, colony formation, migration, and invasion of NB cell lines. Despite the scarcity of information regarding how these complexes work and influence the initiation and maintenance of $\mathrm{NB}$, the fact that the tumorigenic phenotype is reduced or inhibited after depletion of some of these complexes' components represents a great suggestion of their importance in NB. Interestingly, these machineries show a high level of interconnection in terms of shared components, similar binding sites on chromatin, and downstream effects. Further investigations on these potentially druggable regulators might be fundamental for developing new therapeutic strategies to tackle down one or more critical pathways in maintaining a tumorigenic profile in an NB landscape.

\section{NB Regulatory Networks}

While almost half of the encoded human TFs are expressed in every cell type, a restricted subgroup of them, named master TFs, can dictate the expression of cell-typespecific genes, thereby controlling transcriptional programmes in a tissue-specific fashion that will characterise the differentiated cell state (Figure 1). These core TFs are highly expressed in specific cell types, and they tend to co-occupy many enhancer and superenhancer elements within multi-subunit protein complexes [63]. Enhancers typically drive gene transcription of multiple genomic loci, and also display consensus DNA binding sequences for several transcription factors and are found in euchromatic regions. On the 
other hand, super enhancers (SEs) show the same features on a higher level of magnitude: they space for a range of more than $20 \mathrm{~kb}$ on average, have highly dense clusters of TF binding sites, and their genomic loci show outstanding levels of open chromatin histone modifications, such as H3K4me1 and H3K27ac [64]. Overall, SEs exhibit a stronger ability in activating transcription and a more substantial influence on the genes they control (Figure 1) [65].

\section{A}

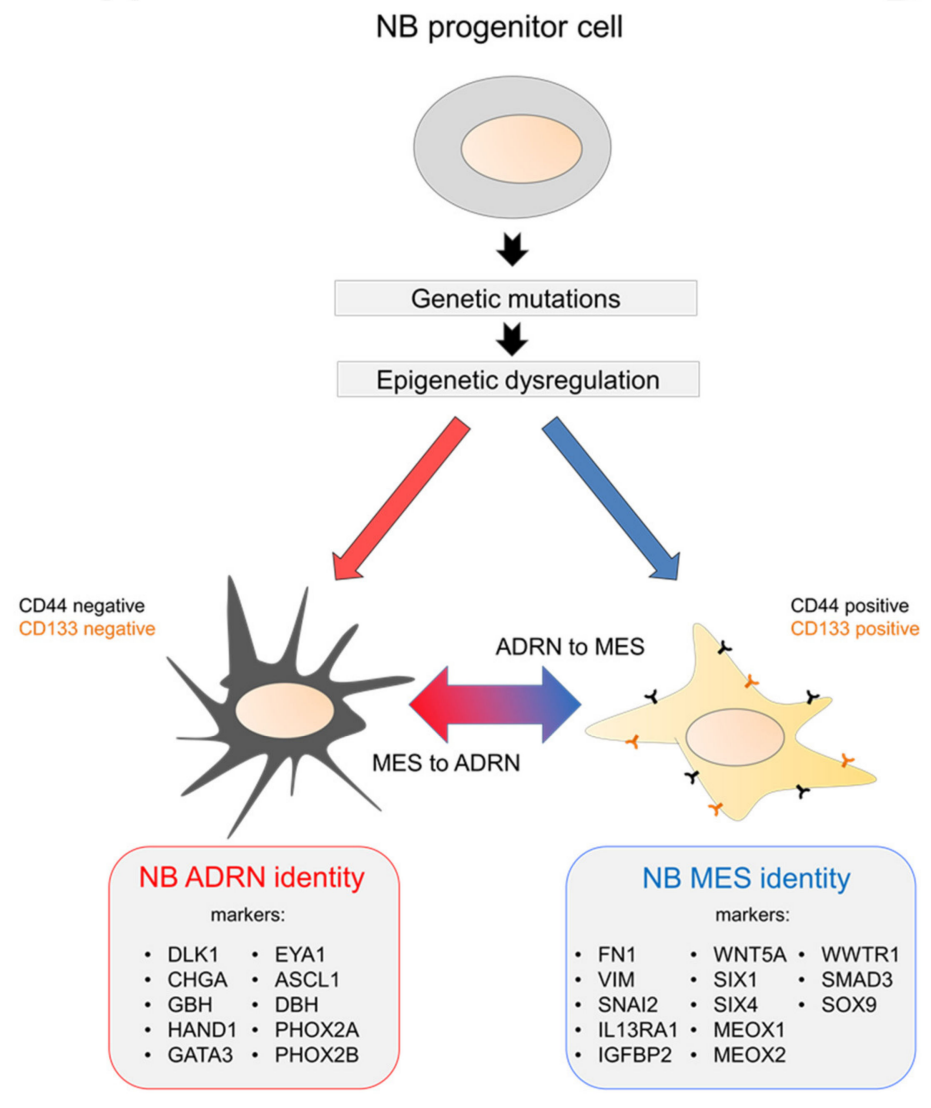

B

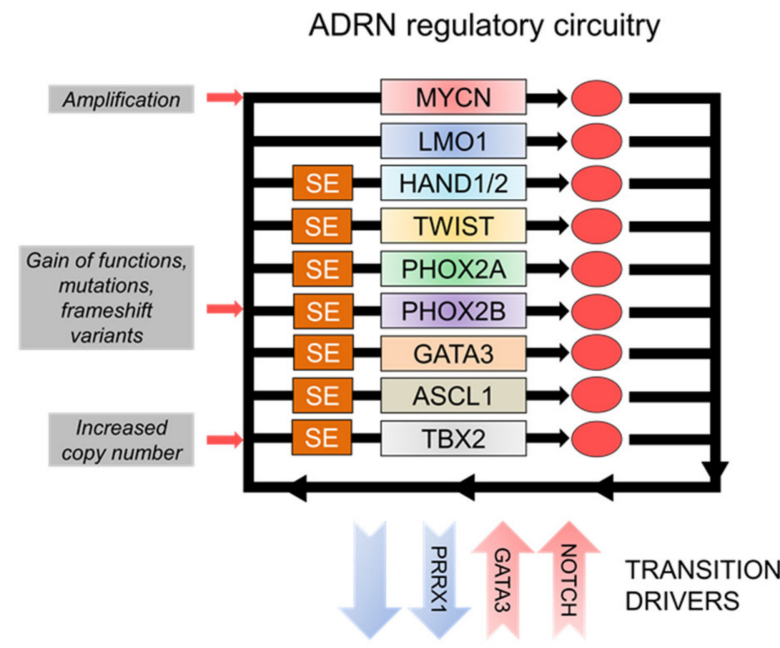

MES regulatory circuitry

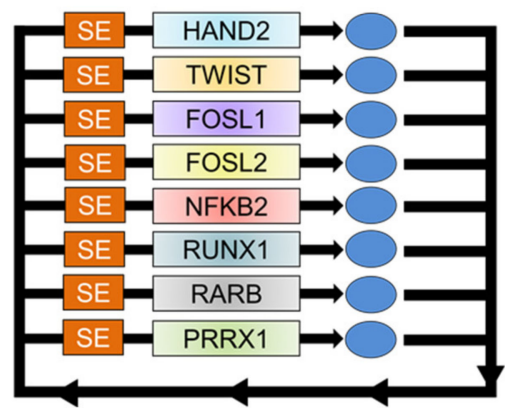

Figure 1. (A)Transition between mesenchymal (MES) and adrenergic (ADRN) neuroblastoma states depends on specific core regulatory circuitries. (B) Convergence of genetic mutations and epigenetic alterations results in oncogenic signalling dysregulation depending on feed-forward core transcriptional circuitries in human NBs. CRCs result in interconnected and autoregulated networks among TFs, which can drive the development of specific subtypes of NBs by establishing distinct gene expression signatures. "SE" refers to "Super Enhancer".

Intriguingly, recent genome-wide H3K27ac profiling in patient-derived NB samples revealed four distinct SE-driven epigenetic subtypes, characterised by their own and specific master regulatory networks. Three of them are named after the known clinical groups: MYCN-amplified, MYCN non-amplified high-risk, and MYCN non-amplified lowrisk NBs, while the fourth displays cellular features which resemble multipotent Schwann cell precursors. Interestingly, the cyclin gene CCND1 was regulated through distinct and shared SEs in the different subtypes, and, more importantly, some tumours showed signals belonging to multiple epigenetic signatures, suggesting that the epigenetic landscape is likely to contribute to intratumoural heterogeneity [45].

The establishment of interconnected and autoregulated networks among TFs represents the core transcriptional regulatory circuitry (CRC) of a cell. In cancer cells, stem and lineage-specific TFs and other epigenetic regulators are often hijacked by cancer-associated CRCs, which are activated to prevent terminal differentiation and reshape tumour cell 
behaviour [63,66-69]. Particularly, in NB, recent evidence reported by several groups, and, notably, by van Groningen and colleagues [70], suggested two predominant types of cell identity among neuroblastoma cell lines. These two groups are defined by highly different phenotypes and divergent gene expression profiles governed by unique core TFs and superenhancer transcriptional networks. The first group, showing a sympathetic-noradrenergic identity, includes committed sympathoadrenal cells (ADRN), while the second group comprises multipotent undifferentiated cells with a neural crest-cell-like or mesenchymal identity, referred to as MES identity (Figure 1) [70-72]. In particular, it was demonstrated that around 369 genes have corresponded with ADRN mRNA expression, and 485 genes associated with MES mRNA expression in four isogenic cell lines. Interestingly, ChIP-seq analyses for H3K4me3 and H3K27ac histone modifications were performed in five ADRN and four MES NB cell lines, revealing around 276 SEs related to the ADRN type, while 286 associated with MES type.

Some essential genes, such as IL13RA1, FN1, IGFBP2, and WNT5A, were associated with MES-specific states, while genes such as DLK1, CHGA, and GBH correspond with ADRN differentiation. Further studies also revealed 20 essential MES TF genes, such as SIX1, SIX4, MEOX1, MEOX2, WWTR1, SMAD3, and SOX9, and about 18 SE-associated TF genes, such as, for example, HAND1, GATA3, EYA1, and ASCL1 $[65,69,73]$.

Moreover, the ADRN and MES cells can transdifferentiate, with paired mesoderm homeobox protein 1 (PRRX1) being the driving factor in promoting the interconversion from the ADR to the MES module, modifying transcriptional programmes and repurposing the adrenergic super-enhancer landscape [70]. The more profound investigation of SK$\mathrm{N}-\mathrm{SH}$ neuroblastoma-derived cells was an exhaustive example to better understand the bidirectional and spontaneous potential of transdifferentiation in NB. Indeed, RNA-seq of SK-N-SH cells identified two phenotypically divergent subclones, characterised by the expression of CD44 as an MES marker [74]. Bulk RNA-seq experiments verified that CD44and CD44+ sorted cells displayed gene expression profiles such as the ADRN SH-SY5Y and the MES SH-EP cells, respectively. The sorted ADRN/CD44- and MES/CD44+ cells can generate a mixed cell population, confirming spontaneous and bidirectional plasticity between these two states [75].

In ADRN cells of NB, downstream Notch activation [76] or overexpression of the transcription factor PRRX1 induces transdifferentiation towards an MES phenotype. Notably, this research team discovered that in vitro treatment of MES NB cells revealed more resistance to frequently used NB medicines, such as cisplatin, doxorubicin, and etoposide, than ADRN NB cells, suggesting an answer to the widespread problem of potential relapses. In addition, in vivo studies showed that PRRX1+ MES cells increase in relapsed tumours and tumours treated with conventional chemotherapy [76].

NBs belonging to the most frequent ADRN group are controlled by a set of superenhancers, including TFs loci such as HAND2, PHOX2A, PHOX2B, GATA2, GATA3, and the ALK oncogene locus [71]. On the other hand, the MES group, significantly associated with relapsed cases, is driven by a CRC module, including AP-1 transcription factor family (FOSL1 and FOSL2), NFKB2, RUNX1, RARB [45], and PRRX1 [77] as major drivers, conferring NCC-like identity. The TFs TWIST and HAND2 are known to be bound to both cell states' regulatory sequences [77].

Several TFs govern the gene expression programmes of neuroblastoma, notably including different CRC transcription factors, such as PHOX2B, HAND2, GATA3, ASCL1, ISL1, and TBX2, which show a clustered binding across open chromatin regions of their regulatory sequences, as well as those of the other CRC partners and those of many other driver master regulators, including MYCN and ALK. This signature array is either unique to NB or only minimally shared with other tumour types [72].

NB's dependence on these master regulators has been proven and confirmed by several research groups via several different approaches, such as transient siRNA-mediated knockdown, footprinting, HiChIP experiments, and functional genomics studies with CRISPR-Cas9 screenings. Indeed, depletion of one of these genes resulted in a reduction in 
cell proliferation, induction of apoptosis, and a concomitant decrease in each CRC gene expression level, demonstrating their interdependent expression [45,71,72]. In addition, the KD of a subtype-related master regulator, specific for ADR or MES identity, strongly correlated with a higher sensitivity of the associated subtype, supporting the notion that these master TFs are required for maintaining a particular neuroblastoma cell state (Figure 1). However, despite considerable efforts, it still remains largely unknown how distinct cell identities can influence neuroblastoma's tumour initiation, progression, and relapse, as well as the molecular events that drive NB development, which are still unclear $[45,78]$.

\section{N-Myc and Other Master Regulators: Oncogenic Drivers in NB Progression}

In the context of NB master regulators, N-Myc plays a crucial role, since its gene amplification is associated with poor prognosis and advanced tumour stages, and is one of the initiating events driving the transformation and progression of high-risk NBs $[19,79,80]$.

As a pivotal oncogenic transcription factor, N-Myc, along with its partner MAX, can activate or repress many genes, thereby orchestrating expression programmes of several targets that cannot be ascribed to a single regulatory pathway. When deregulated, N-Myc governs the cis-regulatory landscape of NB. Among its targets, it co-occupies the same regulatory regions bound by adrenergic $\mathrm{CRC}$ TFs, further promoting the transcription of genes induced by CRC members and reinforcing their expression as well in a model defined by Zeid et al. as "enhancer invasion" [77]. Consequently, loss of N-Myc leads to a reduction in global gene expression levels within the cellular transcriptome and, particularly, of its directly targeted tumour-related genes [81], indicating its determining role in maintaining both normal and altered NB regulatory networks. For this reason, N-Myc may act as a general transcriptional amplifier or, otherwise, as a CRC member [72].

ChIP-seq analyses produced by Zeid and colleagues showed different N-Myc binding profiles: in one case, its classical target genes exhibit the classical promoter occupancy, while, in some others, $\mathrm{N}-\mathrm{Myc}$ shows a more spread promoter and enhancer binding. The latter shape was proved to be associated with crucial neuroblastoma-associated genes, suggesting that only deregulated N-Myc invades pre-established and preacetylated enhancers in order to amplify tissue-specific gene expression and drive oncogenic transformation [77].

In MYCN-amplified NBs, N-Myc is stabilised by several mechanisms and has a leading role in regulating different downstream pathways and proteins, notably including the anaplastic lymphoma kinase (ALK). ALK can be coamplified along with MYCN, and its gain-of-function mutations can potentiate MYCN oncogenic activity [82]. N-Myc and ALK co-operation seems to be due to ALK-mediated activation of RET and MAPK/RAS/PI3Kdependent signalling [19].

The development of MYCN-amplified NBs is also sustained by the action of other protein interactors, such as Aurora A (AURKA), a kinase that has been demonstrated to stabilise the N-Myc protein, inhibiting its degradation. AURKA may inhibit neuroblasts' cell-cycle exit during embryonic and early postnatal development, thereby contributing to NB formation. Notably, AURKA and N-Myc are connected through a positive feedback loop: AURKA is highly expressed in MYCN-amplified NBs, while N-Myc stability is enhanced by this kinase [83].

The action of TWIST1, an already mentioned CRC TF, also sustains MYCN's enhancer axis in MYCN-amplified NBs. TWIST1 and N-Myc recognise similar CANNTG E-boxe DNA sequences and, in addition, their binding sites on enhancers strongly overlap; this suggests crucial oncogenic co-operation between these two TFs in promoting neuroblastoma tumorigenesis and in driving enhancer-dependent gene expression [77]. Additionally, the chromatin regulator WDR5 has been shown to be needed for MYC recruitment on chromatin and, more specifically, to form a protein complex with N-Myc, leading to H3K4 trimethylation and activation of N-Myc targets. Remarkably, the repression of WDR5 resulted in a reduction in NB cell growth and apoptosis. Hence, uncovering this WDR5$\mathrm{N}$-Myc relationship could be useful for developing new therapies against MYC-driven tumours $[84,85]$. 
Among all the factors taking part in NB tumorigenesis, recent genomic and functional investigations highlighted BARD1 [32,86], LMO1, and ASCL1 [81] as important actors in neuroblastoma tumorigenesis as well.

Genome-wide association studies (GWAS) identified common variations at the BARD1 locus to be highly associated with aggressiveness of high-risk neuroblastoma [32,86]. The expression of the full-length isoform of BARD1 has been demonstrated to prevent malignant transformation of NB cells, negatively correlated with high-risk neuroblastoma development. This isoform heterodimerises with BRCA1, and it is required for BRCA1 relocation and its known tumour-suppressive function as a guardian of genetic stability. This evidence indicates BARD1 as a tumour suppressor gene. In contrast, the opposite effect was instead ascribed to cancer-associated BARD1 shorter isoforms: their interaction with the Aurora kinase family antagonises the functions of the full-length isoform, thereby defining them as one of the oncogenic drivers of NB carcinogenesis [32,86].

Recent studies by Wang et al. revealed the implication of LMO1 as a major predisposition gene in NB oncogenesis. LMO proteins operate in NB cells as additional transcriptional cofactors that function as adapters to form complexes between DNA-binding proteins, such as basic helix-loop-helix (bHLH) proteins or GATA proteins. LMO1 acts as an oncogene that collaborates with N-Myc, causing rapid cellular proliferation and arrest of neuroblasts' differentiation into chromaffin cells or sympathetic ganglia. Although the oncogenic pathways downstream of LMO1's transcriptional regulation are unknown, ChIP-seq and RNA-seq analyses revealed that a critical target regulated by LMO1 is ASCL1, a gene encoding a bHLH TF. The regulatory elements of this gene are also bound by all members of the adrenergic neuroblastoma CRC; moreover, ASCL1 and LMO1 proteins can cobind to the enhancers responsible for the regulation of CRC TFs genes, and to the regulatory regions of their target as well. This characteristic occupancy makes them, respectively, a member and a coregulator of the ADRN neuroblastoma CRC [81].

\section{Transcriptional Dysregulated Programmes and Promising Therapeutic Approaches}

The description of the NB landscape through advances in DNA, RNA, and epigenetic profiling reveals the complexity of this pathology $[16,87,88]$. In this regard, it is not surprising that NB research has constantly increased over the years, showing how the extreme variety of genetic and epigenetic backgrounds, mixed with multiple levels of regulatory network regulations, reflect a challenging tumour to investigate. To date, treatment of NB high-risk patients includes an intensive chemotherapy regimen with cisplatin, vincristine, carboplatin, etoposide, and cyclophosphamide (COJEC), followed by resection surgery and myeloablative therapy in combination with haematopoietic stem cell reinfusion and local radiation therapy [89]. The relevance of specific targeted therapy in NB could be crucial considering the standard strategies' weakening approach in treating high-risk patients and the extreme cancer heterogeneity, which spans from spontaneous regressions to metastatic and aggressive diseases (Figure 2) [90]. 


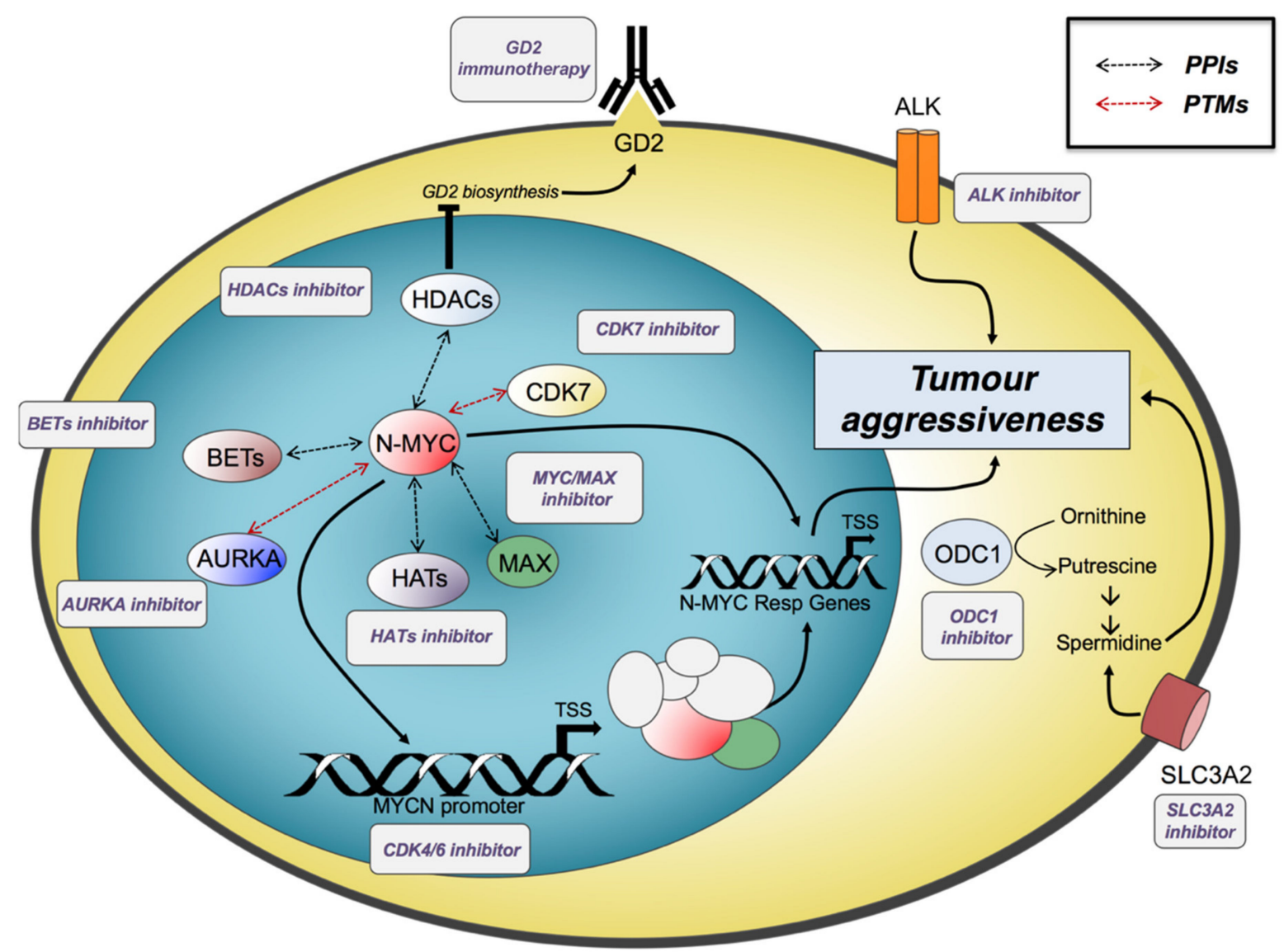

Figure 2. Targeting neuroblastoma oncogenic pathways: N-Myc pathways can be targeted by a direct or indirect approach. Direct targeting can be achieved by blocking the N-Myc/MAX interaction, while indirect targeting can be obtained by inhibiting enzymes involved in N-Myc post-translational modifications (PTMs) or protein-protein interactions (PPIs). Furthermore, HDAC inhibition induces higher expression of GD2, a crucial target for immunotherapy. The N-Mycresponsive gene product ODC1 can be targeted to inhibit spermidine biosynthesis, involved in tumoral aggressive phenotype. Spermidine uptake from the extracellular environment can be blocked by inhibiting the SLC3A2 transporter. ALK inhibitors are successfully used in ALK-mutated NB.

Several biological and genetic markers of this tumour have been understudied to help diagnosis and prognosis, giving relevant insights on the molecular landscape of NB and attention to specific factors. Indeed, the dysregulation of gene expression programmes, biochemical cascades, and metabolic pathways control the aggressiveness of NB, shedding light on some crucial components capable of being directly or indirectly targeted. Activating ALK mutations and N-Myc overexpression were shown to be the most influential de novo oncogenic drivers. Indeed, the regulatory networks dependent on N-Myc and ALK are considerably involved in maintaining the proliferative phenotype and blocking differentiation pathways in neural precursors, as demonstrated by in vitro and in vivo experiments [18].

\subsection{Targeting N-Myc and Its Regulatory Networks}

For instance, the N-Myc-dependent regulatory network drives the malignancy and maintenance of stem-like state by activating the expression of genes involved in metastasis, such as integrins $\alpha 1$ and $\beta 1$, the FAK protein, and metalloproteinases, self-renewal and pluripotency, such as KLF2, KLF4, and LIN28B, survival, and angiogenesis [91-95]. Thus, novel efforts are converging on the investigation of new methods to target MYC to indirectly achieve antitumour effects by disrupting its oncogenic programme's key components. The potential of selectively inhibiting N-Myc would be the most effective approach to counteract 
advanced forms of NB. Indeed, since the high frequency of MYCN amplification in cancer and its role in driving and promoting tumorigenesis, as well as its space-temporal restricted expression during embryo development, precise N-Myc targeting would certainly result in successful therapeutics to support NB treatment (Figure 2) [18,96]. However, the extreme variability in cancer mutations and the presence of homologous forms of Myc proteins are still profoundly affecting the process of selective drug design. Specific N-Myc inhibitor therapy still remains poorly explored [97]. To overcome this issue, the scientific community focuses on alternative approaches that aim to control N-Myc-mediated transcriptional activation and its regulatory networks. Once chromatin undergoes "writers" and "erasers" labelling, it will gain or lose the ability to bind to the "readers". One outstanding example is the bromodomain-containing protein BRD4, which recognises and binds histones with acetylated lysine residues [98]. BRD4 interacts with the positive elongation factor ( $\mathrm{P}-\mathrm{TEFb})$ complex as part of the general transcription machinery. It thereby regulates gene expression by participating in the transcription preinitiation complex assembly [99].

Indeed, N-Myc-mediated transcriptional regulation is promoted mainly by the association with bromodomain and extra terminal (BET)-containing proteins, which work as chromatin "readers" by binding to acetylated lysine residues and helping transcription. The bromodomain-containing protein 2 (BRD2), BRD3, and BRD4 are of great relevance. Several analyses showed that the application of the BET inhibitor JQ1 downregulates $\mathrm{N}-\mathrm{Myc}$ transcriptional signatures, lowering MYCN expression, thus increasing the survival percentage in both xenograft and transgenic murine models of NB (Figure 2) [100].

Although not yet approved by the American agency of Food and Drug Administration (FDA), the application of BETi seems to be one of the most promising approaches to treat NB patients with MYCN amplification. Further proof of this was provided by developing new drugs, such as birabresib (MK-8628-formerly known as OTX015-an orally bioavailable small molecule that prevents BRD2/3/4 from binding to acetylated histones. Recently, Henssen et al. showed that BRD4 specifically occupies N-Myc targets and other genes associated with super-enhancers, and that OTX015 specifically disrupts BRD4 binding to chromatin in NB MYCN-driven murine models, leading to significant survival advantage compared with untreated controls (Table 2) [101]. This study established the therapeutic efficacy of the BET inhibitor OTX015 in preclinical NB studies. Moreover, it confirmed the effectiveness of this drug in phase I trials in adult haematological malignancies (NCT01713582) and solid tumours (NCT02259114), as well as for GSK525762, another BETi under phase I clinical trial for solid tumours, including NB [102]. As an amplifier of active transcription, the modern concept of Myc proteins is constantly evolving compared to the commonly held conclusion that Myc co-ordinates the transcription of distinct groups of genes. This event can be possible since N-Myc can interact with a plethora of proteins, allowing the regulation of several central control points of gene transcription, such as promoter binding, epigenetic modifications, initiation, elongation, and post-transcriptional processes $[58,77,103,104]$. 
Table 2. List of chemical compounds targeting multiple regulatory networks in NB. Inhibitors are classified based on the molecular target/mechanism, preclinical (ncbi), and clinical (FDA) status relative to NB and some paediatric solid tumours updated to 2021. All the references are rereferred to in the "reference" section in the main manuscript.

\begin{tabular}{|c|c|c|c|c|}
\hline Compound & Target/Mechanism & FDA Approval & $\begin{array}{c}\text { Clinical Trial Status } \\
\text { (2021) }\end{array}$ & References \\
\hline Crizotinib & ALK & $\begin{array}{l}\text { NCT03126916 } \\
\text { NCT01606878 } \\
\text { NCT00939770 } \\
\text { NCT03107988 } \\
\text { NCT01121588 }\end{array}$ & $\begin{array}{l}\text { Phase III } \\
\text { Phase I } \\
\text { Phase I/II } \\
\text { Phase I } \\
\text { Phase I }\end{array}$ & [108-112] \\
\hline Alectinib & & - & - & [113-116] \\
\hline Lorlatinib & & $\begin{array}{l}\text { NCT04753658 } \\
\text { NCT03107988 }\end{array}$ & $\begin{array}{l}\text { Observational } \\
\text { Phase I }\end{array}$ & {$[117,118]$} \\
\hline Alisertib & AURKA & $\begin{array}{l}\text { NCT01601535 } \\
\text { NCT02444884 } \\
\text { NCT01154816 }\end{array}$ & $\begin{array}{c}\text { Phase I/II } \\
\text { Phase I } \\
\text { Phase II }\end{array}$ & [119-125] \\
\hline JQ1 & \multirow{3}{*}{$\mathrm{BRD} 2 / 3 / 4$} & - & - & [101,126-130] \\
\hline OTX015 & & $\begin{array}{l}\text { NCT01713582 } \\
\text { NCT02259114 }\end{array}$ & $\begin{array}{l}\text { Phase I } \\
\text { Phase I }\end{array}$ & {$[101,131,132]$} \\
\hline GSK525762 & & NCT01587703 & Phase I/II & {$[133,134]$} \\
\hline Palbociclib & $\mathrm{CDK} 4 / 6$ & $\begin{array}{l}\text { NCT03526250 } \\
\text { NCT03709680 } \\
\text { NCT03155620 }\end{array}$ & $\begin{array}{l}\text { Phase II } \\
\text { Phase I } \\
\text { Phase II }\end{array}$ & {$[135,136]$} \\
\hline Ribociclib (LEE011) & & $\begin{array}{l}\text { NCT01747876 } \\
\text { NCT02780128 } \\
\text { NCT03434262 } \\
\end{array}$ & $\begin{array}{l}\text { Phase I } \\
\text { Phase I } \\
\text { Phase I }\end{array}$ & [137-140] \\
\hline Abemaciclib (LY2835219) & & $\begin{array}{l}\text { NCT02644460 } \\
\text { NCT04238819 }\end{array}$ & $\begin{array}{l}\text { Phase I } \\
\text { Phase I }\end{array}$ & [141] \\
\hline THZ1 & CDK7 & - & - & {$[23,105,106,127]$} \\
\hline CYC065 (fadraciclib) & CDK9/2 & NCT02552953 & Phase I & [107] \\
\hline Carboplatin & DNA synthesis & Approved & Approved & [142-147] \\
\hline Cisplatin & DNA/RNA synthesis & Approved & Approved & [148-150] \\
\hline Cyclophosphamide & $\begin{array}{c}\text { DNA replication/RNA } \\
\text { synthesis }\end{array}$ & Approved & Approved & [151-153] \\
\hline Doxorubicin & DNA/RNA synthesis & Approved & Approved & [154-161] \\
\hline Etoposide & DNA synthesis/Topo II poison & Approved & Approved & {$[142,144,162-164]$} \\
\hline GD2 immunotherapy & GD2 ganglioside & $\begin{array}{l}\text { NCT01822652 } \\
\text { NCT01460901 } \\
\text { NCT01576692 } \\
\text { NCT01953900 } \\
\text { NCT02100930 } \\
\text { NCT01953900 } \\
\text { NCT04539366 }\end{array}$ & $\begin{array}{l}\text { Phase I } \\
\text { Phase I } \\
\text { Phase I } \\
\text { Phase I } \\
\text { Phase I } \\
\text { Phase I } \\
\text { Phase I }\end{array}$ & [165-170] \\
\hline PU139 & HAT & - & - & [61] \\
\hline PU141 & & - & - & [61] \\
\hline P22077 & HAUSP & - & - & [171] \\
\hline Panobinostat & & NCT04897880 & Phase II & {$[23,172-175]$} \\
\hline Valproic acid & HDAC & NCT01204450 & Phase I & [176-181] \\
\hline Vorinostat (SAHA) & & $\begin{array}{l}\text { NCT01019850 } \\
\text { NCT03332667 } \\
\text { NCT03561259 } \\
\text { NCT01208454 } \\
\text { NCT02035137 } \\
\text { NCT02559778 } \\
\text { NCT01132911 } \\
\text { NCT01163383 } \\
\text { NCT04308330 } \\
\text { NCT00217412 }\end{array}$ & $\begin{array}{l}\text { Phase I } \\
\text { Phase I } \\
\text { Phase II } \\
\text { Phase I } \\
\text { Phase II } \\
\text { Phase II } \\
\text { Phase I } \\
\text { Phase II } \\
\text { Phase I } \\
\text { Phase I }\end{array}$ & [182-188] \\
\hline
\end{tabular}


Table 2. Cont.

\begin{tabular}{|c|c|c|c|c|}
\hline Compound & Target/Mechanism & FDA Approval & $\begin{array}{c}\text { Clinical Trial Status } \\
\text { (2021) }\end{array}$ & References \\
\hline 10058-F4 & \multirow{5}{*}{$\begin{array}{l}\text { MYC/MAX heterodimer } \\
\text { inhibitor }\end{array}$} & - & - & [189] \\
\hline 10074-G5 & & - & - & {$[189,190]$} \\
\hline IIA6B17 & & - & - & [191] \\
\hline MYCi361 & & - & - & [192] \\
\hline Omomyc (OMO-103) & & NCT04808362 & Phase I/II & [193-195] \\
\hline DFMO & ODC1 & $\begin{array}{l}\text { NCT02395666 } \\
\text { NCT01586260 } \\
\text { NCT04301843 } \\
\text { NCT01059071 } \\
\text { NCT02679144 } \\
\text { NCT02139397 } \\
\text { NCT02030964 } \\
\text { NCT02030964 }\end{array}$ & $\begin{array}{c}\text { Phase II } \\
\text { Phase II } \\
\text { Phase II } \\
\text { Phase I } \\
\text { Phase II } \\
\text { Phase I/II } \\
\text { Phase I } \\
\text { Phase I }\end{array}$ & [196-202] \\
\hline WS6 & PA2G4 & - & - & [203] \\
\hline AZD8055 & \multirow[t]{4}{*}{$\begin{array}{c}\mathrm{PI} 3 \mathrm{~K} / \mathrm{AKT} / \mathrm{mTOR} \\
\text { pathway }\end{array}$} & $\begin{array}{l}\text { NCT01316809 } \\
\text { NCT00973076 } \\
\text { NCT00731263 } \\
\text { NCT01194193 }\end{array}$ & $\begin{array}{l}\text { Phase I } \\
\text { Phase I } \\
\text { Phase I } \\
\text { Phase I }\end{array}$ & [204-207] \\
\hline Perifosine & & $\begin{array}{l}\text { NCT01049841 } \\
\text { NCT00776867 }\end{array}$ & $\begin{array}{l}\text { Phase I } \\
\text { Phase I }\end{array}$ & [208-210] \\
\hline Picropodophyllin (PPP) & & $\begin{array}{l}\text { NCT01721577 } \\
\text { NCT01725555 } \\
\text { NCT01062620 }\end{array}$ & $\begin{array}{c}\text { Phase I/II } \\
\text { Phase I } \\
\text { Phase I }\end{array}$ & [211] \\
\hline SF1126 & & $\begin{array}{l}\text { NCT02337309 } \\
\text { NCT00907205 }\end{array}$ & $\begin{array}{l}\text { Phase I } \\
\text { Phase I }\end{array}$ & [212] \\
\hline AMXT 1501 & SLC3A2 & NCT03536728 & Phase I & {$[196,202]$} \\
\hline Lapatinib & \multirow{2}{*}{ TK } & - & - & {$[106,213]$} \\
\hline Ponatinib & & - & - & {$[106,214-216]$} \\
\hline
\end{tabular}

RNA polymerase II (RNA Pol II) transcriptional activation is regulated by a specific set of cyclin-dependent kinases (CDKs), including CDK7 (cyclin-dependent kinase 7), a crucial component of the transcription initiation factor TFIIH that phosphorylates RNA Pol II to start transcription. In 2014, Chipumuro et al. reported that a covalent inhibitor of cyclin-dependent kinase 7 (CDK7), THZ1, was found to disrupt the transcription of MYCN-amplified NB cells selectively, leading to global repression of N-Myc-dependent transcriptional amplification and induction of tumour regression in mice models (Figure 2, Table 2) [105]. The substantial selectivity of this compound for cells with MYCN amplification may be attributable to the reduced expression of super-enhancer-associated oncogenic drivers, including the same N-Myc. Combinatorial therapy with THZ1 and the tyrosine kinase inhibitor (TKi) ponatinib and lapatinib, as well as with the HDACi Panobinostat, synergistically induced NB cell apoptosis, leading to NB tumour regression $[23,106]$.

These novel therapeutic approaches are gaining even greater importance considering the effect on the regulation on the CRC and global gene expression, confirming how particularly JQ1 and THZ1 injection can rapidly decrease the expression of CRC mRNA levels after just one hour of treatment in MYCN-amplified NB cells. The expression level of each of the CRC transcription factor genes was dramatically downregulated by the combination of JQ1 and THZ1, with more restricted consequences regarding either drug alone. These results underlined the impact of JQ1 and THZ1 combination treatment in MYCN-amplified $\mathrm{NB}$, although the broad implication of combining transcriptional disruption is still not fully understood [72]. In line with these novel pharmacological strategies, recent studies shed light on the CDK9/2 inhibitor CYC065 (fadraciclib) contribution, resulting in selective loss of nascent MYCN transcription (Table 2). MYCN loss sensitises cells to apoptosis following 
CDK2 inhibition by selectively targeting NB cells characterised with MYCN amplification, confirming the pivotal role of the crosstalk between the components of the transcriptional machinery [107].

\subsubsection{Inhibition of the N-Myc/MAX Interaction}

$\mathrm{N}-\mathrm{Myc}$ is a nuclear intrinsically disordered protein that can exist in distinct complexes within the same cell by interacting with hundreds of components to keep the cell identity [104,217,218].

All the Myc proteins are basic helix-loop-helix/leucine zipper (bHLH/LZ) transcription factors capable of dimerising with the partner MAX (MYC-associated factor X) to regulate up to $10-15 \%$ of all genes. These data assume additional relevance within MYCN biology in NB models, considering how MAX can instruct transcriptional programmes that either reinforce or weaken the oncogenic process enacted by N-Myc [219]. Thus, the N-Myc/MAX heterodimer-controlled inhibition is an attractive approach to counteract the oncogenic regulatory network triggered by MYCN [220]. In 2002, a 7000 peptidomimetic compound screening was performed to select novel candidates capable of preventing the dimerisation between Myc and MAX (Figure 2). This analysis identified IIA6B17 and IIA4B20, two small molecules that exert a strong inhibitory effect on MycMAX dimerisation and DNA binding, characterised by a lower IC50 for Myc compared to the homologous transcription factor Jun [221]. The ground-breaking work of Berg et al. began the development of novel therapeutic interventions to inhibit the MYCN-mediated oncogenic programme. The identification of new drugs, such as 10074-G5, 10058-F4, KJPyr-9, the Myc inhibitor 361 (MYCi361), and the novel Peptomyc's Omomyc-based therapy (OMO-103) brought new hope for the fight against NB disease (Table 2) [88,101,222-224]. Remarkably, just in March 2021, OMO-103 was announced to have obtained approval from the Spanish Agency of Medicines and Medical Devices for conducting a phase I/II clinical trial, proving the efficacy of this innovative approach (NCT04808362).

\subsubsection{Targeting N-Myc Stability}

As for c-MYC, the N-Myc protein degradation is mainly induced by the ubiquitinproteasome system [225]. The discovery of new components affecting the N-Myc protein stability aroused great interest concerning the possibility of developing novel treatments against many MYC-driven tumours. In this framework, AURKA inhibition is making inroads as a promising alternative approach in preclinical models of NB. N-Myc is usually stabilised by direct interaction with AURKA, preventing proteasomal degradation dependent on the SCF-FBXW7 E3 ubiquitin ligase (Figure 2) [83]. Confirming the importance of this topic, the AURKA inhibitor MLN8237 (also known as alisertib) combined with irinotecan and temozolomide chemotherapy is under clinical assessment for multiplecancer relapsed NB (NCT01601535) (Table 2) [182]. The characterisation of a new class of conformation-disrupting inhibitors of AURKA that destabilise interactions between AURKA and N-Myc is enjoying great popularity, proving to be another promising strategy in the next future operations [226]. As for AURKA, WDR5 is emerging as a novel promising MYC vulnerability in cancers [227]. Following this approach, many other drugs, such as the PLK1 inhibitor BI 2356, the HAUSP inhibitor P22077, and the PA2G4 inhibitor WS6, are providing the basis for drug design of small molecules targeting Myc and N-Myc binding partners in malignancies driven by MYC family oncoproteins, representing new alternative forms for the treatment of high-risk NB [203,228,229].

\subsection{Targeting Polyamine Metabolism}

MYCN-amplified NBs show deregulation of several enzymes involved in polyamine metabolisms, such as ODC1, SRM, SMS, AMD1, OAZ2, and SMOX [230]. Polyamines are essential polycations that sustain Myc functions through ionic and covalent activities. The decreased levels of intracellular polyamines stimulate checkpoints that limit proliferation, while enhanced polyamine synthesis supports oncogenic proliferation (Figure 2) [231]; this 
pathway has aroused attention as a therapeutic target in cancers and other hyperproliferative diseases. Moreover, polyamines are involved in several biological processes, and one of the most crucial ones is spermidine. Spermidine is needed for hypusinilation of the translation elongation factor eIF5A, engaged in translating genes containing specific aminoacidic repeats. Hypusinilated eIF5A is essential for translation of genes encoding for proteins involved in the cytoskeletal-associated process, RNA splicing and turnover, DNA binding and transcription, and cell signalling [232]. Notably, ODC1, a key enzyme in polyamine metabolism which converts ornithine to putrescine, is a direct transcription target of N-Myc $[230,233]$. ODC1 is druggable by difluoromethylornithine (DFMO), which recently completed a phase II clinical trial. DFMO treatment after completion of first-line therapy was associated with improved event-free and overall survival compared to controls treated at the same institutions of this clinical trial [233]. The importance of ODC1 was recently underlined by Gamble et al., showing how a G316A promoter single nucleotide polymorphism (SNP) differentially affects ODC1 expression, as well as MYCN-mediated ODC1 transactivation of the E-box region and MYCN oncogenic processes in NB cells in vitro. The underlying molecular mechanism revealed that the $\mathrm{A}$ allele had decreased affinity for the N-Myc protein, indicating that the region surrounding the E-box is critical in modulating ODC1 transcriptional function and an influence on DMFO response (Table 2) [234]. Chemoresistance to DFMO may be due to the upregulation of transporters that drive polyamine uptake from the extracellular environment. SLC3A2 is a transporter able to drive intake polyamines into NB cells, and its inhibition by AMXT 1501 in combination with DFMO was effective in treating NB in mouse models (Table 2) [196]. Combination therapy of AMXT 1501 and DFMO treatment is currently in phase I trial for solid tumours (NCT03536728).

\subsection{Targeting CDK4/6 and PI3K/AKT/mTOR}

On the other hand, N-Myc dysregulation can influence cell cycle progression by upregulating several genes, such as cyclin $\mathrm{D} 2$, E2F proteins, $\mathrm{CDK} 4 / 6$, and $\mathrm{CDC} 2$, resulting in the inactivation of genes involved in the G1 phase and DNA replication (Figure 2) $[235,236]$. These data assume additional relevance in preclinical studies and clinics considering the promising effects of CDK4/6 inhibitors on NB and other paediatric cancers [137-139].

One of the principal pathways accountable for pushing the malignant transformation and drug resistance in solid tumours is the phosphatidylinositol 3-kinase (PI3K) / AKT / mTOR pathway. PI3K is a class of molecules divided into three categories based on structure, regulation, and function [237]. This pathway is taking particular attention after the pioneering work of Opel et al., which showed, in 2007, how the activation of the PI3KAKT-mTOR pathway is a common event in NB tumour samples. This pathway drives the phosphorylation of AKT at threonine 308 (T308) and/or serine 473 (S473), an event that correlates with less overall survival in NB patients with MYCN amplification, 1p36 chromosomal alterations, which drives general decrease in event-free survival [238]. The specific mechanisms by which the PI3K/AKT/mTOR pathway is activated in NB are still not fully understood. Accordingly, the actual hypothesis is that PI3K/AKT/mTOR pathway activation in NB occurs through various mechanisms. Indeed, some scientists advised that the reduced expression of the tumour suppressor PTEN may diminish PI3K signalling through reducing negative regulation on the p110 subunit encoded by the PIK3CA gene [239]. This is supported by several pieces of evidence of reduced PTEN protein levels evaluated in immunohistochemistry, together with an increase in downstream targets of the PI3K pathway in NB [240]. Recent investigations have also underscored mutations in the ALK gene, such as ALK F1174L, capable of increasing, together with N-Myc, the PI3K/AKT/mTOR pathway in a subset of NB [241]. Hence, this phenomenon seems to also be related to TrkB/brain-derived neurotrophic, IGF, EGF, PDGF, and VEGF receptor signalling pathways [242-246]. To date, the PI3K/AKT/mTOR pathway is arousing interest as a novel target for potential novel therapeutic approaches. For example, the selective insulin-like growth factor 1 (IGF-1) receptor inhibitor picropodophyllin (PPP) has been shown to pre- 
vent AKT activation and, consequently, suppress cell proliferation in NB cells. In addition to that, the dual mTORC1-mTORC2 inhibitor AZD8055, the phase I trial SF1126, the phase $\mathrm{I} / \mathrm{II}$ trial copanlisib (PI3K inhibitor), the phase I/Ib trial perifosine (AKT inhibitor), and many other compounds are emerging as great opportunities to fight this overly aggressive disease, marking the significant importance of this molecular pathway (Table 2).

\subsection{Targeting ALK}

Nowadays, mutated ALK is one of the few directly targetable main oncogenes in NB [247]. As discussed previously, the most common ALK mutations found in NB are amplification and point mutation, driving its hyperactivation through autophosphorylation of the tyrosine kinase domain [108]. Several ALK inhibitors have been developed for cancer therapy, and they have been classified as first-, second-, and third-generation ALK inhibitors. Here, we report three representative examples of drugs belonging to each of these categories (Figure 2).

First-generation ALK inhibitor crizotinib is a small-molecule adenosine triphosphate (ATP) - a competitive inhibitor of ALK kinase activity. Crizotinib showed satisfactory results in some paediatric cancers carrying gain-of-function ALK mutation. However, in a phase I clinical trial involving 11 NB patients with known ALK mutation, only one patient with Arg1275Gln mutation experienced complete regression and two patients with Arg1275Gln and Phe1174Leu mutation experienced stable disease [248]. This is consistent with further in vitro data showing enhanced growth inhibition of crizotinib in NB cell lines with Arg1275 mutation than cell lines carrying other mutations [108]. Indeed, crizotinib showed minimal effects on ALK Phe1174 mutations, one of the most common ALK mutations seen in NB. The second-generation ALK inhibitor alectinib induces apoptosis in both ALK wild-type and ALK mutant NB cells, and it is even more effective when combined with HDAC inhibitor vorinostat (Table 2) [113]. However, to our knowledge, there are no clinical studies on NB with this drug. Third-generation ALK inhibitor lorlatinib is one of the most promising molecules for the treatment of ALK-mutated NB. It showed good efficiency in vitro and in vivo in NB cells carrying Arg1275Gln, Phe1174Leu, and Phe1245Cys mutations, and it is currently in phase I study [109] (NCT03107988 NCT04753658). Notably, a recent case report of a patient carrying ALK Phe1174Leu mutation showed a complete response to lorlatinib but, unfortunately, relapsed after 13 months from the treatment (Table 2) [117].

\subsection{Epigenetic Therapies}

In compliance with the low frequency of recurrent somatic mutations, NB is mainly characterised by the dysregulation of a multitude of genetic and epigenetic mechanisms, leading patients to poor outcomes [249]. This cancer model is an outstanding candidate for discovering new epigenetic therapies to overcome drug resistance. As previously discussed, the perturbation of the histone acetylome plays a key role during the whole process of tumorigenesis; indeed, various active molecules targeting histone acetylation regulatory enzymes, such as bromodomains (BRDs), histone deacetylases (HDACs), and histone acetyltransferase (HATs), have been developed to recover abnormal histone acetylation levels due to the dysregulation of these regulatory networks, and some of them were already positively evaluated in clinical trials also (Figure 2) [60].

Based on the vast heterogeneity of the HDAC classes, many studies on different pathologies describe a full-blown uneven cellular response to both the specific and nonspecific HDAC inhibition [196,250]. Consistent with transcriptional addiction, the selective disruption of CRC was accomplished by targeting the acetylation in cancer. Concerning NB, various investigations confirmed the therapeutic potential of HDACi in terms of efficacy, toxicity, and pharmacokinetics (Table 2). One of the key examples is valproic acid, capable of taking the cells to a marked inhibition of cell proliferation, induction of differentiation, suppression of the Warburg effect, and apoptosis [176,251,252]. Consistent with the idea of combinatory drug treatments, valproic acid showed increased therapeutic potential 
in combination with other drugs, such as the DNA-damaging molecule ellipticine [253] (PMID: 29304031), the COX-2 inhibitor celecoxib, the clusterin inhibitor OGX-01170, the angiogenic inhibitor ABT-510, or the more commonly used etoposide and cisplatin, thus proving synergistic effects leading to tumour growth impairment (Table 2) [177,253-256]. A synthetic lethal screening against MYCN-amplified NB revealed that the HDACi vorinostat (also known as SAHA) induces dramatic cell death combined with the proteasome inhibitor bortezomib (BTZ) in part through synergistic activation of BAX. This high-throughput screening was performed using a library containing 938 FDA-approved drugs for candidates that elicit synthetic lethal effects in MYC-driven NB cells. The combination resulted in marked tumour suppression in vivo, supporting dual proteasome/HDAC inhibition as a potential therapeutic approach for MYC-driven cancers [183]. Vorinostat is a selective class I and II HDAC inhibitor in a clinical trial for NB and various cancer treatments. Several studies suggested that vorinostat administration results in G2/M phase arrest, which activates the intrinsic apoptotic pathway [257]. It was also advertised to reduce VEGF secretion, suggesting a potential antiangiogenic effect [258]. Recent scientific articles strongly suggested that vorinostat administration, combined with GD2 immunotherapy, is even more effective in suppressing NB growth in the aggressive orthotopic model, resulting in higher animal survival rates, thus supplying a solid rationale for clinical testing in NB patients $[184,259]$. Moreover, vorinostat can also boost up the antitumour effect of other molecules, such as fenretinide, the pan-CDK inhibitor flavopiridol, and the ALK inhibitor alectinib (Table 2) [260-262].

Finally, recent studies suggested how HDAC inhibition can drive the enhancer remodelling and suppression of oncogenic super-enhancers by disrupting the three-dimensional structure of the chromatin looping and by depleting transcription factors on the same DNA sites $[100,263]$.

\subsection{Immuno Cell Therapy: Targeting GD2}

Immuno-targeting MYCN-amplified NBs are challenging, since N-Myc is involved in downregulation of the major histocompatibility complex (MHC) class I antigen expression, leading to escape from cytotoxic $\mathrm{T}$ cells and interferon-mediated immune response [264,265]. The relationship of MYCN with the tumour immune microenvironment has only begun to be explored [264]. The tumour microenvironment of MYCN-amplified NBs contains a significantly lower number of immune cells compared to the MYCNnonamplified counterpart [266]. For these reasons, the authors of the above-mentioned review describe MYCN-amplified NBs as "cold" and immune exclusive, while MYCNnonamplified are referred to as significantly inflamed or "hot" [264]. Based on this evidence, a more profound comprehension of the microenvironment's role in NB disease could drive novel strategies for the cure of this childhood malignancy (please refer to PMID: 32722460). In fact, the lack of antigen presentation due to MYCN overexpression has been successfully circumvented by developing antibodies against the targetable ganglioside GD2 [267].

Gangliosides are modified sphingolipids highly expressed from cancer cells. Generally, gangliosides are not considered for target therapy because they are also found in healthy tissues. Exceptionally, the ganglioside GD2 is highly expressed on the surface of NB cells, and its expression in normal tissue is limited at a relatively low level to neurons, skin melanocytes, and peripheral nerve fibres (Figure 2) [268]. Moreover, GD2 is virtually expressed in all NBs, regardless of the grade and staging of the tumour [269-271]. These characteristics make GD2 an exciting target for immunotherapy. Currently, dinutuximab is the only monoclonal antibody approved by FDA and EMA for anti-GD2 immunotherapy in NB. It is used in combination with granulocyte-macrophage colony-stimulating factor (GM-CSF), interleukin-2 (IL-2), and 13-cis-retinoic acid (RA) for the treatment of high-risk NB patients who achieve at least a partial response to prior first-line therapy [272]. Dinutuximab is a chimeric antibody (mouse-human) based on the structure of the murine monoclonal antibody 14G2a. The structural characterisation of the 14G2a antibody-antigen complex led to the generation of a specific single-chain variable fragment $(\mathrm{ScFv})$, a useful 
tool for developing new biotechnological therapies [273]. However, limiting factors in GD2 immunotherapy are probably due to the molecular mechanisms regulating GD2 expression in NB that are not yet fully understood (Table 2) $[165,166,274]$. Recent evidence suggests that the enzymes involved in GD2 biosynthesis are controlled by another druggable target in NB: HDACs activity. Kroesen and colleagues demonstrated that expression of GD2 is enhanced by HDACi vorinostat, pan HDACi givinostat, class-I inhibitor entinostat, and an HDAC1,2-specific inhibitor. Their data highlighted that vorinostat induces higher GD2 expression, increasing GD2 synthase protein levels without altering its mRNA levels in the NB cell line, suggesting that HDACs may act at the post-translational level of this enzyme [184]. Moreover, the same research group found that cells that were treated with vorinostat, together with the cell-permeable sialic acid Ac5Neu5Ac, increased the expression of sialyltransferases ST3GAL5 and ST8SIA1, generating GM3 and GD3 gangliosides, the necessary precursors for GD2 synthesis [275]. The combined treatment with engineered sialic acid and HDACi may further increase the efficacy of current and future GD2-targeted immunotherapy in NB patients.

\section{Conclusions}

$\mathrm{NB}$ is one of the topmost common neurogenic extracranial solid cancers occurring in childhood and infancy. The extreme heterogeneity of this pathology is still considered a significant challenge to overcome and assumes a relevant aspect for developing novel therapeutic strategies. Several new pieces of evidence show the critical level of plasticity of this neoplasia, unveiling the role of numerous layers of regulation that drastically influence patient outcomes. This review aims to provide a comprehensive blueprint of the transcriptional regulation bearing NB initiation and progression, unravelling the complexity of this pathology's key oncogenic and tumour suppressive regulatory networks. Some interesting points emerged from our analysis.

Firstly, while most familial NB cases are characterised by a "specific" subset of genetic alterations, the same cannot be said regarding the sporadic ones. Hence, the vast majority of NB patients are distinguished by multiple levels of epigenetic alterations. It is important to underline how this sort of dichotomy between these two subgroups of NBs is just apparent; indeed, the most severe NB cases are characterised by both genetic and epigenetic aberrations, resulting in widespread deregulation of gene expression profiles and disruption of these signalling networks that control proliferation and cellular response. These data lay the groundwork for evaluating the whole contribution of these intricate networks of regulation, which influence the destiny of the patients like a single far-reaching entity. Secondly, most NBs include tumour cells with diverging gene expression profiles: the two main subgroups are the undifferentiated mesenchymal (MES) cells and the committed adrenergic (ADRN) ones, which can interconvert and resemble from different lineage differentiation stages. Once again, NB's identities are not governed by small groups of macromolecules, but by a set of core regulatory circuitries of lineage transcription factors associated with super-enhancers and several protein complexes that drastically influence the fate of the cell. This new evidence demonstrates that cancer cells ${ }^{\prime}$ diverging transcriptional states match with the normal lineage development stages. In particular, lineage transcription factors can lead to transdifferentiation via remodelling the epigenetic and transcriptional landscapes, mimicking the natural interconversion. All this information assumes additional relevance considering the different response of ADRN and MES cells to therapeutics, giving more strength to studying these complex grids of regulation. Third, the more profound investigation of these new vulnerabilities paves the way for developing novel therapeutic approaches, bypassing the difficulties in obtaining compounds against molecules complex to target, such as several master TFs like the same $\mathrm{N}$-Myc protein. The significance of a network-based targeted therapy in neuroblastoma could be of great importance considering the standard strategies' weakening approach in treating high-risk patients (general surgery, chemotherapy, radiotherapy), distinguished by metastatic and aggressive tumours. Although the interplay between regulatory networks 
and oncogenesis has been unequivocally described, more in-depth research into their role in modulating cancerous-unrelated signalling pathways still needs to be carried out. According to the novel findings summarised above, discovering this intricate reticulum of interactions represents invaluable predictive factors for early-onset disease detection.

Author Contributions: Conceptualisation, G.M. and R.C.; investigation, R.C., P.D.R., S.A., M.V., L.C., S.K.Z., G.P., G.M.; data curation, G.M.; writing—original draft preparation, R.C., P.D.R., S.A., M.V., L.C., S.K.Z., G.P., G.M.; writing-review and editing, G.M. and G.P.; funding acquisition, G.M. All authors have read and agreed to the published version of the manuscript.

Funding: This research was funded by Italian Ministry of Research and Education and AIRC foundation.

Institutional Review Board Statement: Not applicable.

Informed Consent Statement: Not applicable.

Data Availability Statement: Not applicable.

Acknowledgments: We thank Roberto Bernardoni, Donatella Manzoni, Manuela Voltattorni, Gaia Vannini, Laudonia Lidia Di Palo, Stefano Miglietta, Valentin Isen, Michele Moretti, Ignazia Militello, and Bianca Aloisi.

Conflicts of Interest: The authors declare no conflict of interest.

$\begin{array}{ll}\text { Abbreviations } \\ \text { The following abbreviations are used in this manuscript: } \\ \text { ADRN } & \text { Adrenergic } \\ \text { BET } & \text { Bromodomain and Extra Terminal } \\ \text { bHLH- } & \text { basic Heli Loop Helix } \\ \text { CDK } & \text { Cyclin Dependent Kinase } \\ \text { ChIP } & \text { Chromatin Immuno Precipitation } \\ \text { CRC } & \text { Core Regulatory Circuitry } \\ \text { EMA } & \text { European Medicines Agency } \\ \text { ESCs } & \text { Embryonic Stem Cells } \\ \text { FDA } & \text { U.S Food and Drug Administration } \\ \text { GWAS } & \text { Genome-Wide Association Studies } \\ \text { HAT } & \text { Histone Acetyl Transferase } \\ \text { HDAC } & \text { Histone DeAcetylase } \\ \text { HMT } & \text { Histone Methyltransferase } \\ \text { INSS } & \text { International NB Staging System } \\ \text { KD } & \text { Knock Down } \\ \text { KO } & \text { Knock Out } \\ \text { MES } & \text { Mesenchymal } \\ \text { NCA } & \text { Numerical Chromosomal Alterations } \\ \text { NSCs } & \text { Neuronal Stem Cells } \\ \text { NGS } & \text { Next Generation Sequencing } \\ \text { NB } & \text { Neuroblastoma } \\ \text { SE } & \text { Super Enhancer } \\ \text { RA } & \text { Retinoic Acid } \\ \text { TARGET } & \text { Therapeutically Applicable Research to generate effective Treatment } \\ \text { TF } & \text { Transcription Factor } \\ \text { WGS } & \text { Whole Genome Sequencing } \\ \end{array}$

\section{References}

1. Bahmad, H.F.; Chamaa, F.; Assi, S.; Chalhoub, R.M.; Abou-Antoun, T.; Abou-Kheir, W. Cancer Stem Cells in Neuroblastoma: Expanding the Therapeutic Frontier. Front. Mol. Neurosci. 2019, 12, 131. [CrossRef] [PubMed]

2. Brodeur, G.M.; Seeger, R.C.; Barrett, A.; Berthold, F.; Castleberry, R.P.; D’Angio, G.; De Bernardi, B.; Evans, A.E.; Favrot, M.; Freeman, A.I. International Criteria for Diagnosis, Staging, and Response to Treatment in Patients with Neuroblastoma. J. Clin. Oncol. 1988, 6, 1874-1881. [CrossRef] 
3. Jiang, M.; Stanke, J.; Lahti, J.M. The connections between Neural Crest Development and Neuroblastoma. Curr. Top. Dev. Biol. 2011, 94, 77-127. [CrossRef] [PubMed]

4. Louis, C.U.; Shohet, J.M. Neuroblastoma: Molecular Pathogenesis and Therapy. Annu. Rev. Med. 2015, 66, 49-63. [CrossRef] [PubMed]

5. Cheung, N.-K.V.; Dyer, M.A. Neuroblastoma: Developmental Biology, Cancer Genomics and Immunotherapy. Nat. Rev. Cancer 2013, 13, 397-411. [CrossRef] [PubMed]

6. Mosse, Y.P.; Laudenslager, M.; Khazi, D.; Carlisle, A.J.; Winter, C.L.; Rappaport, E.; Maris, J.M. Germline PHOX2B Mutation in Hereditary Neuroblastoma. Am. J. Hum. Genet. 2004, 75, 727-730. [CrossRef]

7. Trochet, D.; Bourdeaut, F.; Janoueix-Lerosey, I.; Deville, A.; de Pontual, L.; Schleiermacher, G.; Coze, C.; Philip, N.; Frébourg, T.; Munnich, A.; et al. Germline Mutations of the Paired-like Homeobox 2B (PHOX2B) Gene in Neuroblastoma. Am. J. Hum. Genet. 2004, 74, 761-764. [CrossRef] [PubMed]

8. Pattyn, A.; Morin, X.; Cremer, H.; Goridis, C.; Brunet, J.F. The Homeobox Gene Phox2b Is Essential for the Development of Autonomic Neural Crest Derivatives. Nature 1999, 399, 366-370. [CrossRef]

9. Bachetti, T.; Ceccherini, I. Causative and Common PHOX2B Variants Define a Broad Phenotypic Spectrum. Clin. Genet. 2020, 97, 103-113. [CrossRef]

10. Mossé, Y.P.; Laudenslager, M.; Longo, L.; Cole, K.A.; Wood, A.; Attiyeh, E.F.; Laquaglia, M.J.; Sennett, R.; Lynch, J.E.; Perri, P.; et al. Identification of ALK as a Major Familial Neuroblastoma Predisposition Gene. Nature 2008, 455, 930-935. [CrossRef]

11. Kim, E.K.; Kim, S. ALK Gene Copy Number Gain and Immunohistochemical Expression Status Using Three Antibodies in Neuroblastoma. Pediatr. Dev. Pathol. 2017, 20, 133-141. [CrossRef]

12. Fransson, S.; Hansson, M.; Ruuth, K.; Djos, A.; Berbegall, A.; Javanmardi, N.; Abrahamsson, J.; Palmer, R.H.; Noguera, R.; Hallberg, B.; et al. Intragenic Anaplastic Lymphoma Kinase (ALK) Rearrangements: Translocations as a Novel Mechanism of ALK Activation in Neuroblastoma Tumors. Genes Chromosomes Cancer 2015, 54, 99-109. [CrossRef]

13. Cazes, A.; Louis-Brennetot, C.; Mazot, P.; Dingli, F.; Lombard, B.; Boeva, V.; Daveau, R.; Cappo, J.; Combaret, V.; Schleiermacher, G.; et al. Characterization of Rearrangements Involving the ALK Gene Reveals a Novel Truncated Form Associated with Tumor Aggressiveness in Neuroblastoma. Cancer Res. 2013, 73, 195-204. [CrossRef]

14. Brady, S.W.; Liu, Y.; Ma, X.; Gout, A.M.; Hagiwara, K.; Zhou, X.; Wang, J.; Macias, M.; Chen, X.; Easton, J.; et al. Pan-Neuroblastoma Analysis Reveals Age- and Signature-Associated Driver Alterations. Nat. Commun. 2020, 11, 5183. [CrossRef]

15. Peifer, M.; Hertwig, F.; Roels, F.; Dreidax, D.; Gartlgruber, M.; Menon, R.; Krämer, A.; Roncaioli, J.L.; Sand, F.; Heuckmann, J.M.; et al. Telomerase Activation by Genomic Rearrangements in High-Risk Neuroblastoma. Nature 2015, 526, 700-704. [CrossRef]

16. Molenaar, J.J.; Koster, J.; Zwijnenburg, D.A.; van Sluis, P.; Valentijn, L.J.; van der Ploeg, I.; Hamdi, M.; van Nes, J.; Westerman, B.A.; van Arkel, J.; et al. Sequencing of Neuroblastoma Identifies Chromothripsis and Defects in Neuritogenesis Genes. Nature 2012, 483, 589-593. [CrossRef]

17. Maris, J.M. Recent Advances in Neuroblastoma. N. Engl. J. Med. 2010, 362, 2202-2211. [CrossRef]

18. Huang, M.; Weiss, W.A. Neuroblastoma and MYCN. Cold Spring Harb. Perspect. Med. 2013, 3, a014415. [CrossRef]

19. Matthay, K.K.; Maris, J.M.; Schleiermacher, G.; Nakagawara, A.; Mackall, C.L.; Diller, L.; Weiss, W.A. Neuroblastoma. Nat. Rev. Dis. Primers 2016, 2, 16078. [CrossRef]

20. García-López, J.; Wallace, K.; Otero, J.H.; Olsen, R.; Wang, Y.-D.; Finkelstein, D.; Gudenas, B.L.; Rehg, J.E.; Northcott, P.; Davidoff, A.M.; et al. Large 1p36 Deletions Affecting Arid1a Locus Facilitate Mycn-Driven Oncogenesis in Neuroblastoma. Cell Rep. 2020, 30, 454-464.e5. [CrossRef]

21. Shi, H.; Tao, T.; Abraham, B.J.; Durbin, A.D.; Zimmerman, M.W.; Kadoch, C.; Look, A.T. ARID1A Loss in Neuroblastoma Promotes the Adrenergic-to-Mesenchymal Transition by Regulating Enhancer-Mediated Gene Expression. Sci. Adv. 2020, 6, eaaz3440. [CrossRef]

22. Bown, N.; Cotterill, S.; Lastowska, M.; O’Neill, S.; Pearson, A.D.; Plantaz, D.; Meddeb, M.; Danglot, G.; Brinkschmidt, C.; Christiansen, H.; et al. Gain of Chromosome Arm 17q and Adverse Outcome in Patients with Neuroblastoma. N. Engl. J. Med. 1999, 340, 1954-1961. [CrossRef]

23. Wong, M.; Sun, Y.; Xi, Z.; Milazzo, G.; Poulos, R.C.; Bartenhagen, C.; Bell, J.L.; Mayoh, C.; Ho, N.; Tee, A.E.; et al. JMJD6 Is a Tumorigenic Factor and Therapeutic Target in Neuroblastoma. Nat. Commun. 2019, 10, 3319. [CrossRef] [PubMed]

24. MacArthur, I.C.; Bei, Y.; Garcia, H.D.; Ortiz, M.V.; Toedling, J.; Klironomos, F.; Rolff, J.; Eggert, A.; Schulte, J.H.; Kentsis, A.; et al. Prohibitin Promotes De-Differentiation and Is a Potential Therapeutic Target in Neuroblastoma. JCI Insight 2019, 5, 127130. [CrossRef]

25. Adam, K.; Lesperance, J.; Hunter, T.; Zage, P.E. The Potential Functional Roles of NME1 Histidine Kinase Activity in Neuroblastoma Pathogenesis. Int. J. Mol. Sci. 2020, 21, 3319. [CrossRef]

26. Nagy, Z.; Seneviratne, J.A.; Kanikevich, M.; Chang, W.; Mayoh, C.; Venkat, P.; Du, Y.; Jiang, C.; Salib, A.; Koach, J.; et al. An ALYREF-MYCN Coactivator Complex Drives Neuroblastoma Tumorigenesis through Effects on USP3 and MYCN Stability. Nat. Commun. 2021, 12, 1881. [CrossRef]

27. Juan Ribelles, A.; Barberá, S.; Yáñez, Y.; Gargallo, P.; Segura, V.; Juan, B.; Noguera, R.; Piqueras, M.; Fornés-Ferrer, V.; de Mora, J.F.; et al. Clinical Features of Neuroblastoma With 11q Deletion: An Increase in Relapse Probabilities In Localized And 4S Stages. Sci. Rep. 2019, 9, 13806. [CrossRef] 
28. Campbell, K.; Gastier-Foster, J.M.; Mann, M.; Naranjo, A.H.; Van Ryn, C.; Bagatell, R.; Matthay, K.K.; London, W.B.; Irwin, M.S.; Shimada, H.; et al. Association of MYCN Copy Number with Clinical Features, Tumor Biology, and Outcomes in Neuroblastoma: A Report from the Children's Oncology Group. Cancer 2017, 123, 4224-4235. [CrossRef]

29. Lopez, G.; Conkrite, K.L.; Doepner, M.; Rathi, K.S.; Modi, A.; Vaksman, Z.; Farra, L.M.; Hyson, E.; Noureddine, M.; Wei, J.S.; et al. Somatic Structural Variation Targets Neurodevelopmental Genes and Identifies SHANK2 as a Tumor Suppressor in Neuroblastoma. Genome Res. 2020, 30, 1228-1242. [CrossRef]

30. Valentijn, L.J.; Koster, J.; Zwijnenburg, D.A.; Hasselt, N.E.; van Sluis, P.; Volckmann, R.; van Noesel, M.M.; George, R.E.; Tytgat, G.A.M.; Molenaar, J.J.; et al. TERT Rearrangements Are Frequent in Neuroblastoma and Identify Aggressive Tumors. Nat. Genet. 2015, 47, 1411-1414. [CrossRef]

31. Cheung, N.-K.V.; Zhang, J.; Lu, C.; Parker, M.; Bahrami, A.; Tickoo, S.K.; Heguy, A.; Pappo, A.S.; Federico, S.; Dalton, J.; et al. Association of Age at Diagnosis and Genetic Mutations in Patients with Neuroblastoma. JAMA 2012, 307, 1062-1071. [CrossRef] [PubMed]

32. Zeineldin, M.; Federico, S.; Chen, X.; Fan, Y.; Xu, B.; Stewart, E.; Zhou, X.; Jeon, J.; Griffiths, L.; Nguyen, R.; et al. MYCN Amplification and ATRX Mutations Are Incompatible in Neuroblastoma. Nat. Commun. 2020, 11, 913. [CrossRef] [PubMed]

33. Parodi, S.; Pistorio, A.; Erminio, G.; Ognibene, M.; Morini, M.; Garaventa, A.; Gigliotti, A.R.; Haupt, R.; Frassoni, F.; Pezzolo, A. Loss of Whole Chromosome X Predicts Prognosis of Neuroblastoma Patients with Numerical Genomic Profile. Pediatr. Blood Cancer 2019, 66, e27635. [CrossRef] [PubMed]

34. Berbegall, A.P.; Villamón, E.; Tadeo, I.; Martinsson, T.; Cañete, A.; Castel, V.; Navarro, S.; Noguera, R. Neuroblastoma after Childhood: Prognostic Relevance of Segmental Chromosome Aberrations, ATRX Protein Status, and Immune Cell Infiltration. Neoplasia 2014, 16, 471-480. [CrossRef]

35. Suzuki, M.; Kushner, B.H.; Kramer, K.; Basu, E.M.; Roberts, S.S.; Hammond, W.J.; LaQuaglia, M.P.; Wolden, S.L.; Cheung, N.-K.V.; Modak, S. Treatment and Outcome of Adult-Onset Neuroblastoma. Int. J. Cancer 2018, 143, 1249-1258. [CrossRef]

36. Duan, K.; Dickson, B.C.; Marrano, P.; Thorner, P.S.; Chung, C.T. Adult-Onset Neuroblastoma: Report of Seven Cases with Molecular Genetic Characterization. Genes Chromosomes Cancer 2020, 59, 240-248. [CrossRef]

37. Javanmardi, N.; Fransson, S.; Djos, A.; Sjöberg, R.-M.; Nilsson, S.; Truvé, K.; Kogner, P.; Martinsson, T. Low Frequency ALK Hotspots Mutations In Neuroblastoma Tumours Detected By Ultra-Deep Sequencing: Implications For ALK Inhibitor Treatment. Sci. Rep. 2019, 9, 2199. [CrossRef]

38. Trigg, R.M.; Turner, S.D. ALK in Neuroblastoma: Biological and Therapeutic Implications. Cancers 2018, 10, 113. [CrossRef]

39. O'Neill, S.; Ekstrom, L.; Lastowska, M.; Roberts, P.; Brodeur, G.M.; Kees, U.R.; Schwab, M.; Bown, N. MYCN Amplification and 17q in Neuroblastoma: Evidence for Structural Association. Genes Chromosomes Cancer 2001, 30, 87-90. [CrossRef]

40. Chang, M.T.; Asthana, S.; Gao, S.P.; Lee, B.H.; Chapman, J.S.; Kandoth, C.; Gao, J.; Socci, N.D.; Solit, D.B.; Olshen, A.B.; et al. Identifying Recurrent Mutations in Cancer Reveals Widespread Lineage Diversity and Mutational Specificity. Nat. Biotechnol. 2016, 34, 155-163. [CrossRef]

41. Cerami, E.; Gao, J.; Dogrusoz, U.; Gross, B.E.; Sumer, S.O.; Aksoy, B.A.; Jacobsen, A.; Byrne, C.J.; Heuer, M.L.; Larsson, E.; et al. The CBio Cancer Genomics Portal: An Open Platform for Exploring Multidimensional Cancer Genomics Data. Cancer Discov. 2012, 2, 401-404. [CrossRef]

42. Gao, J.; Aksoy, B.A.; Dogrusoz, U.; Dresdner, G.; Gross, B.; Sumer, S.O.; Sun, Y.; Jacobsen, A.; Sinha, R.; Larsson, E.; et al. Integrative Analysis of Complex Cancer Genomics and Clinical Profiles Using the CBioPortal. Sci. Signal. 2013, 6, pl1. [CrossRef]

43. Pugh, T.J.; Morozova, O.; Attiyeh, E.F.; Asgharzadeh, S.; Wei, J.S.; Auclair, D.; Carter, S.L.; Cibulskis, K.; Hanna, M.; Kiezun, A.; et al. The Genetic Landscape of High-Risk Neuroblastoma. Nat. Genet. 2013, 45, 279-284. [CrossRef]

44. Biswas, S.; Rao, C.M. Epigenetic Tools (The Writers, The Readers and The Erasers) and Their Implications in Cancer Therapy. Eur. J. Pharm. 2018, 837, 8-24. [CrossRef]

45. Gartlgruber, M.; Sharma, A.K.; Quintero, A.; Dreidax, D.; Jansky, S.; Park, Y.-G.; Kreth, S.; Meder, J.; Doncevic, D.; Saary, P.; et al. Super Enhancers Define Regulatory Subtypes and Cell Identity in Neuroblastoma. Nat. Cancer 2021, 2, 114-128. [CrossRef]

46. Burney, M.J.; Johnston, C.; Wong, K.-Y.; Teng, S.-W.; Beglopoulos, V.; Stanton, L.W.; Williams, B.P.; Bithell, A.; Buckley, N.J. An Epigenetic Signature of Developmental Potential in Neural Stem Cells and Early Neurons. Stem Cells 2013, 31, 1868-1880. [CrossRef]

47. Delaval, K.; Feil, R. Epigenetic Regulation of Mammalian Genomic Imprinting. Curr. Opin. Genet. Dev. 2004, 14, 188-195. [CrossRef]

48. Margueron, R.; Trojer, P.; Reinberg, D. The Key to Development: Interpreting the Histone Code? Curr. Opin. Genet. Dev. 2005, 15, 163-176. [CrossRef]

49. Tsai, H.-C.; Baylin, S.B. Cancer Epigenetics: Linking Basic Biology to Clinical Medicine. Cell Res. 2011, 21, 502-517. [CrossRef]

50. Bernstein, B.E.; Mikkelsen, T.S.; Xie, X.; Kamal, M.; Huebert, D.J.; Cuff, J.; Fry, B.; Meissner, A.; Wernig, M.; Plath, K.; et al. A Bivalent Chromatin Structure Marks Key Developmental Genes in Embryonic Stem Cells. Cell 2006, 125, 315-326. [CrossRef]

51. Sharma, S.V.; Lee, D.Y.; Li, B.; Quinlan, M.P.; Takahashi, F.; Maheswaran, S.; McDermott, U.; Azizian, N.; Zou, L.; Fischbach, M.A.; et al. A Chromatin-Mediated Reversible Drug-Tolerant State in Cancer Cell Subpopulations. Cell 2010, 141, 69-80. [CrossRef] 
52. Cohen, A.L.; Piccolo, S.R.; Cheng, L.; Soldi, R.; Han, B.; Johnson, W.E.; Bild, A.H. Genomic Pathway Analysis Reveals That EZH2 and HDAC4 Represent Mutually Exclusive Epigenetic Pathways across Human Cancers. BMC Med. Genom. 2013, 6, 35. [CrossRef]

53. Corvetta, D.; Chayka, O.; Gherardi, S.; D'Acunto, C.W.; Cantilena, S.; Valli, E.; Piotrowska, I.; Perini, G.; Sala, A. Physical Interaction between MYCN Oncogene and Polycomb Repressive Complex 2 (PRC2) in Neuroblastoma: Functional and Therapeutic Implications. J. Biol. Chem. 2013, 288, 8332-8341. [CrossRef]

54. Chen, L.; Alexe, G.; Dharia, N.V.; Ross, L.; Iniguez, A.B.; Conway, A.S.; Wang, E.J.; Veschi, V.; Lam, N.; Qi, J.; et al. CRISPR-Cas9 Screen Reveals a MYCN-Amplified Neuroblastoma Dependency on EZH2. J. Clin. Investig. 2018, 128, 446-462. [CrossRef]

55. Tsubota, S.; Kishida, S.; Shimamura, T.; Ohira, M.; Yamashita, S.; Cao, D.; Kiyonari, S.; Ushijima, T.; Kadomatsu, K. PRC2Mediated Transcriptomic Alterations at the Embryonic Stage Govern Tumorigenesis and Clinical Outcome in MYCN-Driven Neuroblastoma. Cancer Res. 2017, 77, 5259-5271. [CrossRef]

56. Li, Z.; Takenobu, H.; Setyawati, A.N.; Akita, N.; Haruta, M.; Satoh, S.; Shinno, Y.; Chikaraishi, K.; Mukae, K.; Akter, J.; et al. EZH2 Regulates Neuroblastoma Cell Differentiation via NTRK1 Promoter Epigenetic Modifications. Oncogene 2018, 37, $2714-2727$. [CrossRef]

57. Schulte, J.H.; Lim, S.; Schramm, A.; Friedrichs, N.; Koster, J.; Versteeg, R.; Ora, I.; Pajtler, K.; Klein-Hitpass, L.; Kuhfittig-Kulle, S.; et al. Lysine-Specific Demethylase 1 Is Strongly Expressed in Poorly Differentiated Neuroblastoma: Implications for Therapy. Cancer Res. 2009, 69, 2065-2071. [CrossRef] [PubMed]

58. Walz, S.; Lorenzin, F.; Morton, J.; Wiese, K.E.; von Eyss, B.; Herold, S.; Rycak, L.; Dumay-Odelot, H.; Karim, S.; Bartkuhn, M.; et al. Activation and Repression by Oncogenic MYC Shape Tumour-Specific Gene Expression Profiles. Nature 2014, 511, 483-487. [CrossRef]

59. Gartel, A.L.; Shchors, K. Mechanisms of C-Myc-Mediated Transcriptional Repression of Growth Arrest Genes. Exp. Cell Res. 2003, 283, 17-21. [CrossRef]

60. Milazzo, G.; Mercatelli, D.; Di Muzio, G.; Triboli, L.; De Rosa, P.; Perini, G.; Giorgi, F.M. Histone Deacetylases (HDACs): Evolution, Specificity, Role in Transcriptional Complexes, and Pharmacological Actionability. Genes 2020, 11, 556. [CrossRef]

61. Gajer, J.M.; Furdas, S.D.; Gründer, A.; Gothwal, M.; Heinicke, U.; Keller, K.; Colland, F.; Fulda, S.; Pahl, H.L.; Fichtner, I.; et al. Histone Acetyltransferase Inhibitors Block Neuroblastoma Cell Growth in Vivo. Oncogenesis 2015, 4, e137. [CrossRef] [PubMed]

62. Yang, H.; Li, Q.; Zhao, W.; Yuan, D.; Zhao, H.; Zhou, Y. MiR-329 Suppresses the Growth and Motility of Neuroblastoma by Targeting KDM1A. FEBS Lett. 2014, 588, 192-197. [CrossRef] [PubMed]

63. Chen, Y.; Xu, L.; Lin, R.Y.-T.; Müschen, M.; Koeffler, H.P. Core Transcriptional Regulatory Circuitries in Cancer. Oncogene 2020, 39, 6633-6646. [CrossRef]

64. Tang, F.; Yang, Z.; Tan, Y.; Li, Y. Super-Enhancer Function and Its Application in Cancer Targeted Therapy. NPJ Precis. Oncol. 2020, 4, 2. [CrossRef]

65. Whyte, W.A.; Orlando, D.A.; Hnisz, D.; Abraham, B.J.; Lin, C.Y.; Kagey, M.H.; Rahl, P.B.; Lee, T.I.; Young, R.A. Master Transcription Factors and Mediator Establish Super-Enhancers at Key Cell Identity Genes. Cell 2013, 153, 307-319. [CrossRef]

66. Bradner, J.E.; Hnisz, D.; Young, R.A. Transcriptional Addiction in Cancer. Cell 2017, 168, 629-643. [CrossRef]

67. Vaquerizas, J.M.; Kummerfeld, S.K.; Teichmann, S.A.; Luscombe, N.M. A Census of Human Transcription Factors: Function, Expression and Evolution. Nat. Rev. Genet. 2009, 10, 252-263. [CrossRef]

68. Garraway, L.A.; Lander, E.S. Lessons from the Cancer Genome. Cell 2013, 153, 17-37. [CrossRef]

69. Hnisz, D.; Abraham, B.J.; Lee, T.I.; Lau, A.; Saint-André, V.; Sigova, A.A.; Hoke, H.A.; Young, R.A. Super-Enhancers in the Control of Cell Identity and Disease. Cell 2013, 155, 934-947. [CrossRef]

70. van Groningen, T.; Koster, J.; Valentijn, L.J.; Zwijnenburg, D.A.; Akogul, N.; Hasselt, N.E.; Broekmans, M.; Haneveld, F.; Nowakowska, N.E.; Bras, J.; et al. Neuroblastoma Is Composed of Two Super-Enhancer-Associated Differentiation States. Nat. Genet. 2017, 49, 1261-1266. [CrossRef]

71. Boeva, V.; Louis-Brennetot, C.; Peltier, A.; Durand, S.; Pierre-Eugène, C.; Raynal, V.; Etchevers, H.C.; Thomas, S.; Lermine, A.; Daudigeos-Dubus, E.; et al. Heterogeneity of Neuroblastoma Cell Identity Defined by Transcriptional Circuitries. Nat. Genet. 2017, 49, 1408-1413. [CrossRef] [PubMed]

72. Durbin, A.D.; Zimmerman, M.W.; Dharia, N.V.; Abraham, B.J.; Iniguez, A.B.; Weichert-Leahey, N.; He, S.; Krill-Burger, J.M.; Root, D.E.; Vazquez, F.; et al. Selective Gene Dependencies in MYCN-Amplified Neuroblastoma Include the Core Transcriptional Regulatory Circuitry. Nat. Genet. 2018, 50, 1240-1246. [CrossRef] [PubMed]

73. Young, R.A. Control of the Embryonic Stem Cell State. Cell 2011, 144, 940-954. [CrossRef] [PubMed]

74. Fernando, J.; Malfettone, A.; Cepeda, E.B.; Vilarrasa-Blasi, R.; Bertran, E.; Raimondi, G.; Fabra, À.; Alvarez-Barrientos, A.; Fernández-Salguero, P.; Fernández-Rodríguez, C.M.; et al. A Mesenchymal-like Phenotype and Expression of CD44 Predict Lack of Apoptotic Response to Sorafenib in Liver Tumor Cells. Int. J. Cancer 2015, 136, E161-E172. [CrossRef]

75. Interplay between Intrinsic Reprogramming Potential and Microenvironment Controls Neuroblastoma Cell Plasticity and Identity I bioRxiv. Available online: https:/ / www.biorxiv.org/content/10.1101/2021.01.07.425710v3 (accessed on 15 October 2021).

76. Van Groningen, T.; Akogul, N.; Westerhout, E.M.; Chan, A.; Hasselt, N.E.; Zwijnenburg, D.A.; Broekmans, M.; Stroeken, P.; Haneveld, F.; Hooijer, G.K.J.; et al. A NOTCH Feed-Forward Loop Drives Reprogramming from Adrenergic to Mesenchymal State in Neuroblastoma. Nat. Commun. 2019, 10, 1530. [CrossRef] 
77. Zeid, R.; Lawlor, M.A.; Poon, E.; Reyes, J.M.; Fulciniti, M.; Lopez, M.A.; Scott, T.G.; Nabet, B.; Erb, M.A.; Winter, G.E.; et al. Enhancer Invasion Shapes MYCN-Dependent Transcriptional Amplification in Neuroblastoma. Nat. Genet. 2018, 50, 515-523. [CrossRef]

78. Capasso, M.; Lasorsa, V.A.; Cimmino, F.; Avitabile, M.; Cantalupo, S.; Montella, A.; De Angelis, B.; Morini, M.; de Torres, C.; Castellano, A.; et al. Transcription Factors Involved in Tumorigenesis Are Over-Represented in Mutated Active DNA-Binding Sites in Neuroblastoma. Cancer Res. 2020, 80, 382-393. [CrossRef]

79. Zimmerman, K.A.; Yancopoulos, G.D.; Collum, R.G.; Smith, R.K.; Kohl, N.E.; Denis, K.A.; Nau, M.M.; Witte, O.N.; Toran-Allerand, D.; Gee, C.E. Differential Expression of Myc Family Genes during Murine Development. Nature 1986, 319, 780-783. [CrossRef]

80. Zimmerman, M.W.; Liu, Y.; He, S.; Durbin, A.D.; Abraham, B.J.; Easton, J.; Shao, Y.; Xu, B.; Zhu, S.; Zhang, X.; et al. MYC Drives a Subset of High-Risk Pediatric Neuroblastomas and Is Activated through Mechanisms Including Enhancer Hijacking and Focal Enhancer Amplification. Cancer Discov. 2018, 8, 320-335. [CrossRef]

81. Wang, L.; Tan, T.K.; Durbin, A.D.; Zimmerman, M.W.; Abraham, B.J.; Tan, S.H.; Ngoc, P.C.T.; Weichert-Leahey, N.; Akahane, K.; Lawton, L.N.; et al. ASCL1 Is a MYCN- and LMO1-Dependent Member of the Adrenergic Neuroblastoma Core Regulatory Circuitry. Nat. Commun. 2019, 10, 5622. [CrossRef]

82. Otte, J.; Dyberg, C.; Pepich, A.; Johnsen, J.I. MYCN Function in Neuroblastoma Development. Front. Oncol. 2020, 10, 624079. [CrossRef]

83. Otto, T.; Horn, S.; Brockmann, M.; Eilers, U.; Schüttrumpf, L.; Popov, N.; Kenney, A.M.; Schulte, J.H.; Beijersbergen, R.; Christiansen, H.; et al. Stabilization of N-Myc Is a Critical Function of Aurora A in Human Neuroblastoma. Cancer Cell 2009, 15, 67-78. [CrossRef]

84. Thomas, L.R.; Wang, Q.; Grieb, B.C.; Phan, J.; Foshage, A.M.; Sun, Q.; Olejniczak, E.T.; Clark, T.; Dey, S.; Lorey, S.; et al. Interaction with WDR5 Promotes Target Gene Recognition and Tumorigenesis by MYC. Mol. Cell 2015, 58, 440-452. [CrossRef]

85. Sun, Y.; Bell, J.L.; Carter, D.; Gherardi, S.; Poulos, R.C.; Milazzo, G.; Wong, J.W.H.; Al-Awar, R.; Tee, A.E.; Liu, P.Y.; et al. WDR5 Supports an N-Myc Transcriptional Complex That Drives a Protumorigenic Gene Expression Signature in Neuroblastoma. Cancer Res. 2015, 75, 5143-5154. [CrossRef]

86. Cimmino, F.; Avitabile, M.; Diskin, S.J.; Vaksman, Z.; Pignataro, P.; Formicola, D.; Cardinale, A.; Testori, A.; Koster, J.; de Torres, C.; et al. Fine Mapping of 2q35 High-Risk Neuroblastoma Locus Reveals Independent Functional Risk Variants and Suggests Full-Length BARD1 as Tumor-Suppressor. Int. J. Cancer 2018, 143, 2828-2837. [CrossRef]

87. Kocak, H.; Ackermann, S.; Hero, B.; Kahlert, Y.; Oberthuer, A.; Juraeva, D.; Roels, F.; Theissen, J.; Westermann, F.; Deubzer, H.; et al. Hox-C9 Activates the Intrinsic Pathway of Apoptosis and Is Associated with Spontaneous Regression in Neuroblastoma. Cell Death Dis. 2013, 4, e586. [CrossRef]

88. Harenza, J.L.; Diamond, M.A.; Adams, R.N.; Song, M.M.; Davidson, H.L.; Hart, L.S.; Dent, M.H.; Fortina, P.; Reynolds, C.P.; Maris, J.M. Transcriptomic Profiling of 39 Commonly-Used Neuroblastoma Cell Lines. Sci. Data 2017, 4, 170033. [CrossRef]

89. Pearson, A.D.J.; Pinkerton, C.R.; Lewis, I.J.; Imeson, J.; Ellershaw, C.; Machin, D.; European Neuroblastoma Study Group. Children's Cancer and Leukaemia Group (CCLG formerly United Kingdom Children's Cancer Study Group) High-Dose Rapid and Standard Induction Chemotherapy for Patients Aged over 1 Year with Stage 4 Neuroblastoma: A Randomised Trial. Lancet Oncol. 2008, 9, 247-256. [CrossRef]

90. Luo, Y.-B.; Cui, X.-C.; Yang, L.; Zhang, D.; Wang, J.-X. Advances in the Surgical Treatment of Neuroblastoma. Chin. Med. J. 2018, 131, 2332-2337. [CrossRef]

91. Van Golen, C.M.; Soules, M.E.; Grauman, A.R.; Feldman, E.L. N-Myc Overexpression Leads to Decreased Beta1 Integrin Expression and Increased Apoptosis in Human Neuroblastoma Cells. Oncogene 2003, 22, 2664-2673. [CrossRef]

92. Tanaka, N.; Fukuzawa, M. MYCN Downregulates Integrin Alpha1 to Promote Invasion of Human Neuroblastoma Cells. Int. J. Oncol. 2008, 33, 815-821.

93. Sugiura, Y.; Shimada, H.; Seeger, R.C.; Laug, W.E.; DeClerck, Y.A. Matrix Metalloproteinases-2 and -9 Are Expressed in Human Neuroblastoma: Contribution of Stromal Cells to Their Production and Correlation with Metastasis. Cancer Res. 1998, 58, 2209-2216.

94. Noujaim, D.; van Golen, C.M.; van Golen, K.L.; Grauman, A.; Feldman, E.L. N-Myc and Bcl-2 Coexpression Induces MMP-2 Secretion and Activation in Human Neuroblastoma Cells. Oncogene 2002, 21, 4549-4557. [CrossRef]

95. Cotterman, R.; Knoepfler, P.S. N-Myc Regulates Expression of Pluripotency Genes in Neuroblastoma Including Lif, Klf2, Klf4, and Lin28b. PLoS ONE 2009, 4, e5799. [CrossRef]

96. Mugrauer, G.; Alt, F.W.; Ekblom, P. N-Myc Proto-Oncogene Expression during Organogenesis in the Developing Mouse as Revealed by in Situ Hybridization. J. Cell Biol. 1988, 107, 1325-1335. [CrossRef]

97. Fletcher, S.; Prochownik, E.V. Small-Molecule Inhibitors of the Myc Oncoprotein. Biochim. Biophys. Acta 2015, 1849, 525-543. [CrossRef]

98. Mujtaba, S.; Zeng, L.; Zhou, M.-M. Structure and Acetyl-Lysine Recognition of the Bromodomain. Oncogene 2007, 26, 5521-5527. [CrossRef]

99. Itzen, F.; Greifenberg, A.K.; Bösken, C.A.; Geyer, M. Brd4 Activates P-TEFb for RNA Polymerase II CTD Phosphorylation. Nucleic Acids Res. 2014, 42, 7577-7590. [CrossRef] 
100. Puissant, A.; Frumm, S.M.; Alexe, G.; Bassil, C.F.; Qi, J.; Chanthery, Y.H.; Nekritz, E.A.; Zeid, R.; Gustafson, W.C.; Greninger, P.; et al. Targeting MYCN in Neuroblastoma by BET Bromodomain Inhibition. Cancer Discov. 2013, 3, 308-323. [CrossRef] [PubMed]

101. Henssen, A.; Althoff, K.; Odersky, A.; Beckers, A.; Koche, R.; Speleman, F.; Schäfers, S.; Bell, E.; Nortmeyer, M.; Westermann, F.; et al. Targeting MYCN-Driven Transcription By BET-Bromodomain Inhibition. Clin. Cancer Res. 2016, 22, 2470-2481. [CrossRef] [PubMed]

102. Piha-Paul, S.A.; Hann, C.L.; French, C.A.; Cousin, S.; Braña, I.; Cassier, P.A.; Moreno, V.; de Bono, J.S.; Harward, S.D.; Ferron-Brady, G.; et al. Phase 1 Study of Molibresib (GSK525762), a Bromodomain and Extra-Terminal Domain Protein Inhibitor, in NUT Carcinoma and Other Solid Tumors. JNCI Cancer Spectr. 2020, 4, pkz093. [CrossRef] [PubMed]

103. Sabò, A.; Kress, T.R.; Pelizzola, M.; de Pretis, S.; Gorski, M.M.; Tesi, A.; Morelli, M.J.; Bora, P.; Doni, M.; Verrecchia, A.; et al. Selective Transcriptional Regulation by Myc in Cellular Growth Control and Lymphomagenesis. Nature 2014, 511, 488-492. [CrossRef] [PubMed]

104. Lourenco, C.; Resetca, D.; Redel, C.; Lin, P.; MacDonald, A.S.; Ciaccio, R.; Kenney, T.M.G.; Wei, Y.; Andrews, D.W.; Sunnerhagen, M.; et al. MYC Protein Interactors in Gene Transcription and Cancer. Nat. Rev. Cancer 2021, 21, 579-591. [CrossRef] [PubMed]

105. Chipumuro, E.; Marco, E.; Christensen, C.L.; Kwiatkowski, N.; Zhang, T.; Hatheway, C.M.; Abraham, B.J.; Sharma, B.; Yeung, C.; Altabef, A.; et al. CDK7 Inhibition Suppresses Super-Enhancer-Linked Oncogenic Transcription in MYCN-Driven Cancer. Cell 2014, 159, 1126-1139. [CrossRef] [PubMed]

106. Tee, A.E.; Ciampa, O.C.; Wong, M.; Fletcher, J.I.; Kamili, A.; Chen, J.; Ho, N.; Sun, Y.; Carter, D.R.; Cheung, B.B.; et al. Combination Therapy with the CDK7 Inhibitor and the Tyrosine Kinase Inhibitor Exerts Synergistic Anticancer Effects against MYCN-Amplified Neuroblastoma. Int. J. Cancer 2020, 147, 1928-1938. [CrossRef]

107. Poon, E.; Liang, T.; Jamin, Y.; Walz, S.; Kwok, C.; Hakkert, A.; Barker, K.; Urban, Z.; Thway, K.; Zeid, R.; et al. Orally Bioavailable CDK9/2 Inhibitor Shows Mechanism-Based Therapeutic Potential in MYCN-Driven Neuroblastoma. J. Clin. Investig. 2020, 130, 5875-5892. [CrossRef]

108. Bresler, S.C.; Weiser, D.A.; Huwe, P.J.; Park, J.H.; Krytska, K.; Ryles, H.; Laudenslager, M.; Rappaport, E.F.; Wood, A.C.; McGrady, P.W.; et al. ALK Mutations Confer Differential Oncogenic Activation and Sensitivity to ALK Inhibition Therapy in Neuroblastoma. Cancer Cell 2014, 26, 682-694. [CrossRef]

109. Infarinato, N.R.; Park, J.H.; Krytska, K.; Ryles, H.T.; Sano, R.; Szigety, K.M.; Li, Y.; Zou, H.Y.; Lee, N.V.; Smeal, T.; et al. The ALK/ROS1 Inhibitor PF-06463922 Overcomes Primary Resistance to Crizotinib in ALK-Driven Neuroblastoma. Cancer Discov. 2016, 6, 96-107. [CrossRef]

110. Sekimizu, M.; Osumi, T.; Fukano, R.; Koga, Y.; Kada, A.; Saito, A.M.; Mori, T. A Phase I/II Study of Crizotinib for Recurrent or Refractory Anaplastic Lymphoma Kinase-Positive Anaplastic Large Cell Lymphoma and a Phase I Study of Crizotinib for Recurrent or Refractory Neuroblastoma: Study Protocol for a Multicenter Single-Arm Open-Label Trial. Acta Med. Okayama 2018, 72, 431-436. [CrossRef]

111. Krytska, K.; Ryles, H.T.; Sano, R.; Raman, P.; Infarinato, N.R.; Hansel, T.D.; Makena, M.R.; Song, M.M.; Reynolds, C.P.; Mossé, Y.P. Crizotinib Synergizes with Chemotherapy in Preclinical Models of Neuroblastoma. Clin. Cancer Res. 2016, 22, 948-960. [CrossRef]

112. Zhang, L.; Wu, B.; Baruchel, S. Oral Metronomic Topotecan Sensitizes Crizotinib Antitumor Activity in ALKF1174L Drug-Resistant Neuroblastoma Preclinical Models. Transl. Oncol. 2017, 10, 604-611. [CrossRef]

113. Lu, J.; Guan, S.; Zhao, Y.; Yu, Y.; Woodfield, S.E.; Zhang, H.; Yang, K.L.; Bieerkehazhi, S.; Qi, L.; Li, X.; et al. The SecondGeneration ALK Inhibitor Alectinib Effectively Induces Apoptosis in Human Neuroblastoma Cells and Inhibits Tumor Growth in a TH-MYCN Transgenic Neuroblastoma Mouse Model. Cancer Lett. 2017, 400, 61-68. [CrossRef]

114. Alam, M.W.; Borenäs, M.; Lind, D.E.; Cervantes-Madrid, D.; Umapathy, G.; Palmer, R.H.; Hallberg, B. Alectinib, an Anaplastic Lymphoma Kinase Inhibitor, Abolishes ALK Activity and Growth in ALK-Positive Neuroblastoma Cells. Front. Oncol. 2019, 9 , 579. [CrossRef]

115. Heath, J.A.; Campbell, M.A.; Thomas, A.; Solomon, B. Good Clinical Response to Alectinib, a Second Generation ALK Inhibitor, in Refractory Neuroblastoma. Pediatr. Blood Cancer 2018, 65, e27055. [CrossRef]

116. Carneiro, B.A.; Pamarthy, S.; Shah, A.N.; Sagar, V.; Unno, K.; Han, H.; Yang, X.J.; Costa, R.B.; Nagy, R.J.; Lanman, R.B.; et al. Anaplastic Lymphoma Kinase Mutation (ALK F1174C) in Small Cell Carcinoma of the Prostate and Molecular Response to Alectinib. Clin. Cancer Res. 2018, 24, 2732-2739. [CrossRef]

117. Liu, T.; Merguerian, M.D.; Rowe, S.P.; Pratilas, C.A.; Chen, A.R.; Ladle, B.H. Exceptional Response to the ALK and ROS1 Inhibitor Lorlatinib and Subsequent Mechanism of Resistance in Relapsed ALK F1174L-Mutated Neuroblastoma. Cold Spring Harb. Mol. Case Stud. 2021, 7, a006064. [CrossRef]

118. Redaelli, S.; Ceccon, M.; Zappa, M.; Sharma, G.G.; Mastini, C.; Mauri, M.; Nigoghossian, M.; Massimino, L.; Cordani, N.; Farina, F.; et al. Lorlatinib Treatment Elicits Multiple On- and Off-Target Mechanisms of Resistance in ALK-Driven Cancer. Cancer Res. 2018, 78, 6866-6880. [CrossRef]

119. Yang, Y.; Ding, L.; Zhou, Q.; Fen, L.; Cao, Y.; Sun, J.; Zhou, X.; Liu, A. Silencing of AURKA Augments the Antitumor Efficacy of the AURKA Inhibitor MLN8237 on Neuroblastoma Cells. Cancer Cell Int. 2020, 20, 9. [CrossRef]

120. Muscal, J.A.; Scorsone, K.A.; Zhang, L.; Ecsedy, J.A.; Berg, S.L. Additive Effects of Vorinostat and MLN8237 in Pediatric Leukemia, Medulloblastoma, and Neuroblastoma Cell Lines. Investig. New Drugs 2013, 31, 39-45. [CrossRef] 
121. Hara, J. Development of Treatment Strategies for Advanced Neuroblastoma. Int. J. Clin. Oncol 2012, 17, 196-203. [CrossRef]

122. Michaelis, M.; Selt, F.; Rothweiler, F.; Löschmann, N.; Nüsse, B.; Dirks, W.G.; Zehner, R.; Cinatl, J. Aurora Kinases as Targets in Drug-Resistant Neuroblastoma Cells. PLoS ONE 2014, 9, e108758. [CrossRef]

123. Carol, H.; Boehm, I.; Reynolds, C.P.; Kang, M.H.; Maris, J.M.; Morton, C.L.; Gorlick, R.; Kolb, E.A.; Keir, S.T.; Wu, J.; et al. Efficacy and Pharmacokinetic/Pharmacodynamic Evaluation of the Aurora Kinase A Inhibitor MLN8237 against Preclinical Models of Pediatric Cancer. Cancer Chemother. Pharmacol. 2011, 68, 1291-1304. [CrossRef]

124. Felgenhauer, J.; Tomino, L.; Selich-Anderson, J.; Bopp, E.; Shah, N. Dual BRD4 and AURKA Inhibition Is Synergistic against MYCN-Amplified and Nonamplified Neuroblastoma. Neoplasia 2018, 20, 965-974. [CrossRef]

125. Romain, C.V.; Paul, P.; Lee, S.; Qiao, J.; Chung, D.H. Targeting Aurora Kinase A Inhibits Hypoxia-Mediated Neuroblastoma Cell Tumorigenesis. Anticancer Res. 2014, 34, 2269-2274.

126. Melaiu, O.; Mina, M.; Chierici, M.; Boldrini, R.; Jurman, G.; Romania, P.; D'Alicandro, V.; Benedetti, M.C.; Castellano, A.; Liu, T.; et al. PD-L1 Is a Therapeutic Target of the Bromodomain Inhibitor JQ1 and, Combined with HLA Class I, a Promising Prognostic Biomarker in Neuroblastoma. Clin. Cancer Res. 2017, 23, 4462-4472. [CrossRef]

127. Decaesteker, B.; Denecker, G.; Van Neste, C.; Dolman, E.M.; Van Loocke, W.; Gartlgruber, M.; Nunes, C.; De Vloed, F.; Depuydt, P.; Verboom, K.; et al. TBX2 Is a Neuroblastoma Core Regulatory Circuitry Component Enhancing MYCN/FOXM1 Reactivation of DREAM Targets. Nat. Commun. 2018, 9, 4866. [CrossRef] [PubMed]

128. Lee, S.; Rellinger, E.J.; Kim, K.W.; Craig, B.T.; Romain, C.V.; Qiao, J.; Chung, D.H. Bromodomain and Extraterminal Inhibition Blocks Tumor Progression and Promotes Differentiation in Neuroblastoma. Surgery 2015, 158, 819-826. [CrossRef]

129. Slavish, P.J.; Chi, L.; Yun, M.-K.; Tsurkan, L.; Martinez, N.E.; Jonchere, B.; Chai, S.C.; Connelly, M.; Waddell, M.B.; Das, S.; et al. Bromodomain-Selective BET Inhibitors Are Potent Antitumor Agents against MYC-Driven Pediatric Cancer. Cancer Res. 2020, 80, 3507-3518. [CrossRef] [PubMed]

130. Shahbazi, J.; Liu, P.Y.; Atmadibrata, B.; Bradner, J.E.; Marshall, G.M.; Lock, R.B.; Liu, T. The Bromodomain Inhibitor JQ1 and the Histone Deacetylase Inhibitor Panobinostat Synergistically Reduce N-Myc Expression and Induce Anticancer Effects. Clin. Cancer Res. 2016, 22, 2534-2544. [CrossRef] [PubMed]

131. Chen, J.; Nelson, C.; Wong, M.; Tee, A.E.; Liu, P.Y.; La, T.; Fletcher, J.I.; Kamili, A.; Mayoh, C.; Bartenhagen, C.; et al. Targeted Therapy of TERT-Rearranged Neuroblastoma with BET Bromodomain Inhibitor and Proteasome Inhibitor Combination Therapy. Clin. Cancer Res. 2021, 27, 1438-1451. [CrossRef] [PubMed]

132. Maser, T.; Zagorski, J.; Kelly, S.; Ostrander, A.; Goodyke, A.; Nagulapally, A.; Bond, J.; Park, Y.; Saulnier Sholler, G. The MDM2 Inhibitor CGM097 Combined with the BET Inhibitor OTX015 Induces Cell Death and Inhibits Tumor Growth in Models of Neuroblastoma. Cancer Med. 2020, 9, 8144-8158. [CrossRef]

133. Healy, J.R.; Hart, L.S.; Shazad, A.L.; Gagliardi, M.E.; Tsang, M.; Elias, J.; Ruden, J.; Farrel, A.; Rokita, J.L.; Li, Y.; et al. Limited Antitumor Activity of Combined BET and MEK Inhibition in Neuroblastoma. Pediatr. Blood Cancer 2020, 67, e28267. [CrossRef]

134. Wyce, A.; Ganji, G.; Smitheman, K.N.; Chung, C.-W.; Korenchuk, S.; Bai, Y.; Barbash, O.; Le, B.; Craggs, P.D.; McCabe, M.T.; et al. BET Inhibition Silences Expression of MYCN and BCL2 and Induces Cytotoxicity in Neuroblastoma Tumor Models. PLoS ONE 2013, 8, e72967. [CrossRef]

135. Rihani, A.; Vandesompele, J.; Speleman, F.; Van Maerken, T. Inhibition of CDK4/6 as a Novel Therapeutic Option for Neuroblastoma. Cancer Cell Int. 2015, 15, 76. [CrossRef]

136. Swadi, R.R.; Sampat, K.; Herrmann, A.; Losty, P.D.; See, V.; Moss, D.J. CDK Inhibitors Reduce Cell Proliferation and Reverse Hypoxia-Induced Metastasis of Neuroblastoma Tumours in a Chick Embryo Model. Sci. Rep. 2019, 9, 9136. [CrossRef]

137. Rader, J.; Russell, M.R.; Hart, L.S.; Nakazawa, M.S.; Belcastro, L.T.; Martinez, D.; Li, Y.; Carpenter, E.L.; Attiyeh, E.F.; Diskin, S.J.; et al. Dual CDK4/CDK6 Inhibition Induces Cell-Cycle Arrest and Senescence in Neuroblastoma. Clin. Cancer Res. 2013, 19, 6173-6182. [CrossRef]

138. Hart, L.S.; Rader, J.; Raman, P.; Batra, V.; Russell, M.R.; Tsang, M.; Gagliardi, M.; Chen, L.; Martinez, D.; Li, Y.; et al. Preclinical Therapeutic Synergy of MEK1/2 and CDK4/6 Inhibition in Neuroblastoma. Clin. Cancer Res. 2017, 23, 1785-1796. [CrossRef]

139. Geoerger, B.; Bourdeaut, F.; DuBois, S.G.; Fischer, M.; Geller, J.I.; Gottardo, N.G.; Marabelle, A.; Pearson, A.D.J.; Modak, S.; Cash, T.; et al. A Phase I Study of the CDK4/6 Inhibitor Ribociclib (LEE011) in Pediatric Patients with Malignant Rhabdoid Tumors, Neuroblastoma, and Other Solid Tumors. Clin. Cancer Res. 2017, 23, 2433-2441. [CrossRef]

140. Wood, A.C.; Krytska, K.; Ryles, H.T.; Infarinato, N.R.; Sano, R.; Hansel, T.D.; Hart, L.S.; King, F.J.; Smith, T.R.; Ainscow, E.; et al. Dual ALK and CDK4/6 Inhibition Demonstrates Synergy against Neuroblastoma. Clin. Cancer Res. 2017, 23, $2856-2868$. [CrossRef]

141. Schubert, N.A.; Schild, L.; van Oirschot, S.; Keller, K.M.; Alles, L.K.; Vernooij, L.; Nulle, M.E.; Dolman, M.E.M.; van den Boogaard, M.L.; Molenaar, J.J. Combined Targeting of the P53 and PRb Pathway in Neuroblastoma Does Not Lead to Synergistic Responses. Eur. J. Cancer 2021, 142, 1-9. [CrossRef]

142. Ladenstein, R.; Pötschger, U.; Pearson, A.D.J.; Brock, P.; Luksch, R.; Castel, V.; Yaniv, I.; Papadakis, V.; Laureys, G.; Malis, J.; et al. Busulfan and Melphalan versus Carboplatin, Etoposide, and Melphalan as High-Dose Chemotherapy for High-Risk Neuroblastoma (HR-NBL1/SIOPEN): An International, Randomised, Multi-Arm, Open-Label, Phase 3 Trial. Lancet Oncol. 2017, 18, 500-514. [CrossRef]

143. Xu, J.; Liu, Z.; Liu, Y.; Wu, G.; Zeng, L.; Xu, J. The Inhibitory Effect of Carboplatin Injection on Human Neuroblastoma SK-N-SH. Cell Transpl. 2020, 29, 963689720920815. [CrossRef] 
144. Park, J.R.; Kreissman, S.G.; London, W.B.; Naranjo, A.; Cohn, S.L.; Hogarty, M.D.; Tenney, S.C.; Haas-Kogan, D.; Shaw, P.J.; Kraveka, J.M.; et al. Effect of Tandem Autologous Stem Cell Transplant vs Single Transplant on Event-Free Survival in Patients With High-Risk Neuroblastoma: A Randomized Clinical Trial. JAMA 2019, 322, 746-755. [CrossRef]

145. Baker, D.L.; Schmidt, M.L.; Cohn, S.L.; Maris, J.M.; London, W.B.; Buxton, A.; Stram, D.; Castleberry, R.P.; Shimada, H.; Sandler, A.; et al. Outcome after Reduced Chemotherapy for Intermediate-Risk Neuroblastoma. N. Engl. J. Med. 2010, 363, 1313-1323. [CrossRef] [PubMed]

146. Hawley, J.; Veal, G.J;; Errington, J.; McDonald, L.G.; Tweddle, D.A. The Use of Pharmacokinetically Guided Carboplatin Chemotherapy in a Pre-Term Infant with Neuroblastoma-Associated Spinal Cord Compression. Pediatr. Blood Cancer 2019, 66, e27825. [CrossRef] [PubMed]

147. Twist, C.J.; Naranjo, A.; Schmidt, M.L.; Tenney, S.C.; Cohn, S.L.; Meany, H.J.; Mattei, P.; Adkins, E.S.; Shimada, H.; London, W.B.; et al. Defining Risk Factors for Chemotherapeutic Intervention in Infants With Stage 4S Neuroblastoma: A Report From Children's Oncology Group Study ANBL0531. J. Clin. Oncol. 2019, 37, 115-124. [CrossRef] [PubMed]

148. Yanagisawa, R.; Kubota, N.; Hidaka, E.; Sakashita, K.; Tanaka, M.; Nakazawa, Y.; Nakamura, T. Cisplatin-Induced Nephrotoxicity in Patients with Advanced Neuroblastoma. Pediatr. Blood Cancer 2018, 65, e27253. [CrossRef] [PubMed]

149. Lee, S.-I.; Jeong, Y.J.; Yu, A.-R.; Kwak, H.J.; Cha, J.-Y.; Kang, I.; Yeo, E.-J. Carfilzomib Enhances Cisplatin-Induced Apoptosis in SK-N-BE(2)-M17 Human Neuroblastoma Cells. Sci. Rep. 2019, 9, 5039. [CrossRef]

150. Yavuz, B.; Zeki, J.; Taylor, J.; Harrington, K.; Coburn, J.M.; Ikegaki, N.; Kaplan, D.L.; Chiu, B. Silk Reservoirs for Local Delivery of Cisplatin for Neuroblastoma Treatment: In Vitro and In Vivo Evaluations. J. Pharm. Sci. 2019, 108, 2748-2755. [CrossRef]

151. Yogev, O.; Almeida, G.S.; Barker, K.T.; George, S.L.; Kwok, C.; Campbell, J.; Zarowiecki, M.; Kleftogiannis, D.; Smith, L.M.; Hallsworth, A.; et al. In Vivo Modeling of Chemoresistant Neuroblastoma Provides New Insights into Chemorefractory Disease and Metastasis. Cancer Res. 2019, 79, 5382-5393. [CrossRef]

152. Saylors, R.L.; Stine, K.C.; Sullivan, J.; Kepner, J.L.; Wall, D.A.; Bernstein, M.L.; Harris, M.B.; Hayashi, R.; Vietti, T.J. Pediatric Oncology Group Cyclophosphamide plus Topotecan in Children with Recurrent or Refractory Solid Tumors: A Pediatric Oncology Group Phase II Study. J. Clin. Oncol. 2001, 19, 3463-3469. [CrossRef]

153. Rujkijyanont, P.; Photia, A.; Traivaree, C.; Monsereenusorn, C.; Anurathapan, U.; Seksarn, P.; Sosothikul, D.; Techavichit, P.; Sanpakit, K.; Phuakpet, K.; et al. Clinical Outcomes and Prognostic Factors to Predict Treatment Response in High Risk Neuroblastoma Patients Receiving Topotecan and Cyclophosphamide Containing Induction Regimen: A Prospective Multicenter Study. BMC Cancer 2019, 19, 961. [CrossRef]

154. Sagnella, S.M.; Trieu, J.; Brahmbhatt, H.; MacDiarmid, J.A.; MacMillan, A.; Whan, R.M.; Fife, C.M.; McCarroll, J.A.; Gifford, A.J.; Ziegler, D.S.; et al. Targeted Doxorubicin-Loaded Bacterially Derived Nano-Cells for the Treatment of Neuroblastoma. Mol. Cancer Ther. 2018, 17, 1012-1023. [CrossRef]

155. Li, Y.; Zhuo, B.; Yin, Y.; Han, T.; Li, S.; Li, Z.; Wang, J. Anti-Cancer Effect of Oncolytic Adenovirus-Armed ShRNA Targeting MYCN Gene on Doxorubicin-Resistant Neuroblastoma Cells. Biochem. Biophys. Res. Commun. 2017, 491, 134-139. [CrossRef]

156. Vittorio, O.; Le Grand, M.; Makharza, S.A.; Curcio, M.; Tucci, P.; Iemma, F.; Nicoletta, F.P.; Hampel, S.; Cirillo, G. Doxorubicin Synergism and Resistance Reversal in Human Neuroblastoma BE(2)C Cell Lines: An in Vitro Study with Dextran-Catechin Nanohybrids. Eur. J. Pharm. Biopharm. 2018, 122, 176-185. [CrossRef]

157. Tan, W.-Q.; Chen, G.; Ye, M.; Jia, B. Artemether Regulates Chemosensitivity to Doxorubicin via Regulation of B7-H3 in Human Neuroblastoma Cells. Med. Sci. Monit. 2017, 23, 4252-4259. [CrossRef]

158. Lebedev, T.D.; Vagapova, E.R.; Astashkova, O.O.; Spirin, P.V.; Prassolov, V.S. Inhibition of Non-Receptor Tyrosine Kinase JAK2 Reduces Neuroblastoma Cell Growth and Enhances the Action of Doxorubicin. Mol. Biol. 2020, 54, 293-299. [CrossRef]

159. Tran, H.C.; Marachelian, A.; Venkatramani, R.; Jubran, R.F.; Mascarenhas, L. Oxaliplatin and Doxorubicin for Relapsed or Refractory High-Risk Neuroblastoma. Pediatr. Hematol. Oncol. 2015, 32, 26-31. [CrossRef]

160. Namkaew, J.; Jaroonwitchawan, T.; Rujanapun, N.; Saelee, J.; Noisa, P. Combined Effects of Curcumin and Doxorubicin on Cell Death and Cell Migration of SH-SY5Y Human Neuroblastoma Cells. In Vitro Cell. Dev. Biol. Anim. 2018, 54, 629-639. [CrossRef]

161. Hultman, I.; Haeggblom, L.; Rognmo, I.; Jansson Edqvist, J.; Blomberg, E.; Ali, R.; Phillips, L.; Sandstedt, B.; Kogner, P.; Shirazi Fard, S.; et al. Doxorubicin-Provoked Increase of Mitotic Activity and Concomitant Drain of G0-Pool in Therapy-Resistant BE(2)-C Neuroblastoma. PLoS ONE 2018, 13, e0190970. [CrossRef]

162. Valter, K.; Maximchik, P.; Abdrakhmanov, A.; Senichkin, V.; Zhivotovsky, B.; Gogvadze, V. Distinct Effects of Etoposide on Glutamine-Addicted Neuroblastoma. Cell Mol. Life Sci. 2020, 77, 1197-1207. [CrossRef]

163. Hiramatsu, T.; Yoshizawa, J.; Miyaguni, K.; Sugihara, T.; Harada, A.; Kaji, S.; Uchida, G.; Kanamori, D.; Baba, Y.; Ashizuka, S.; et al. Thalidomide Potentiates Etoposide-Induced Apoptosis in Murine Neuroblastoma through Suppression of NF-KB Activation. Pediatr. Surg. Int. 2018, 34, 443-450. [CrossRef]

164. Coughlan, D.; Gianferante, M.; Lynch, C.F.; Stevens, J.L.; Harlan, L.C. Treatment and Survival of Childhood Neuroblastoma: Evidence from a Population-Based Study in the United States. Pediatr. Hematol. Oncol. 2017, 34, 320-330. [CrossRef] [PubMed]

165. Richman, S.A.; Nunez-Cruz, S.; Moghimi, B.; Li, L.Z.; Gershenson, Z.T.; Mourelatos, Z.; Barrett, D.M.; Grupp, S.A.; Milone, M.C. High-Affinity GD2-Specific CAR T Cells Induce Fatal Encephalitis in a Preclinical Neuroblastoma Model. Cancer Immunol. Res. 2018, 6, 36-46. [CrossRef]

166. Moghimi, B.; Muthugounder, S.; Jambon, S.; Tibbetts, R.; Hung, L.; Bassiri, H.; Hogarty, M.D.; Barrett, D.M.; Shimada, H.; Asgharzadeh, S. Preclinical Assessment of the Efficacy and Specificity of GD2-B7H3 SynNotch CAR-T in Metastatic Neuroblastoma. Nat. Commun. 2021, 12, 511. [CrossRef] [PubMed] 
167. Sait, S.; Modak, S. Anti-GD2 Immunotherapy for Neuroblastoma. Expert Rev. Anticancer Ther. 2017, 17, 889-904. [CrossRef] [PubMed]

168. Voeller, J.; Sondel, P.M. Advances in Anti-GD2 Immunotherapy for Treatment of High-Risk Neuroblastoma. J. Pediatr. Hematol. Oncol. 2019, 41, 163-169. [CrossRef]

169. Richards, R.M.; Sotillo, E.; Majzner, R.G. CAR T Cell Therapy for Neuroblastoma. Front. Immunol. 2018, 9, 2380. [CrossRef]

170. Heczey, A.; Courtney, A.N.; Montalbano, A.; Robinson, S.; Liu, K.; Li, M.; Ghatwai, N.; Dakhova, O.; Liu, B.; Raveh-Sadka, T.; et al. Anti-GD2 CAR-NKT Cells in Patients with Relapsed or Refractory Neuroblastoma: An Interim Analysis. Nat. Med. 2020, 26, 1686-1690. [CrossRef]

171. Fan, Y.-H.; Cheng, J.; Vasudevan, S.A.; Dou, J.; Zhang, H.; Patel, R.H.; Ma, I.T.; Rojas, Y.; Zhao, Y.; Yu, Y.; et al. USP7 Inhibitor P22077 Inhibits Neuroblastoma Growth via Inducing P53-Mediated Apoptosis. Cell Death Dis. 2013, 4, e867. [CrossRef]

172. Zareifar, S.; Shakibazad, N.; Zekavat, O.R.; Bordbar, M.; Shahriari, M. Successful Treatment of Refractory Metastatic Neuroblastoma with Panobinostat in Combination with Chemotherapy Agents and Iodine-131-Meta-Iodobenzylguanidine Therapy. J. Oncol. Pharm. Pract. 2020, 26, 481-486. [CrossRef]

173. Wang, G.; Edwards, H.; Caldwell, J.T.; Buck, S.A.; Qing, W.Y.; Taub, J.W.; Ge, Y.; Wang, Z. Panobinostat Synergistically Enhances the Cytotoxic Effects of Cisplatin, Doxorubicin or Etoposide on High-Risk Neuroblastoma Cells. PLoS ONE 2013, 8, e76662. [CrossRef]

174. Jose, G.; Lu, Y.-J.; Hung, J.-T.; Yu, A.L.; Chen, J.-P. Co-Delivery of CPT-11 and Panobinostat with Anti-GD2 Antibody Conjugated Immunoliposomes for Targeted Combination Chemotherapy. Cancers 2020, 12, 3211. [CrossRef]

175. Xiao, L.; Somers, K.; Murray, J.; Pandher, R.; Karsa, M.; Ronca, E.; Bongers, A.; Terry, R.; Ehteda, A.; Gamble, L.D.; et al. Dual Targeting of Chromatin Stability By The Curaxin CBL0137 and Histone Deacetylase Inhibitor Panobinostat Shows Significant Preclinical Efficacy in Neuroblastoma. Clin. Cancer Res. 2021, 27, 4338-4352. [CrossRef]

176. Fang, E.; Wang, J.; Hong, M.; Zheng, L.; Tong, Q. Valproic Acid Suppresses Warburg Effect and Tumor Progression in Neuroblastoma. Biochem. Biophys. Res. Commun. 2019, 508, 9-16. [CrossRef]

177. Chen, Y.; Tsai, Y.-H.; Tseng, S.-H. Combined Valproic Acid and Celecoxib Treatment Induced Synergistic Cytotoxicity and Apoptosis in Neuroblastoma Cells. Anticancer Res. 2011, 31, 2231-2239.

178. Hu, T.-M.; Chung, H.-S.; Ping, L.-Y.; Hsu, S.-H.; Tsai, H.-Y.; Chen, S.-J.; Cheng, M.-C. Differential Expression of Multiple Disease-Related Protein Groups Induced by Valproic Acid in Human SH-SY5Y Neuroblastoma Cells. Brain Sci. 2020, 10, 545. [CrossRef]

179. Dedoni, S.; Marras, L.; Olianas, M.C.; Ingianni, A.; Onali, P. Downregulation of TrkB Expression and Signaling by Valproic Acid and Other Histone Deacetylase Inhibitors. J. Pharm. Exp. Ther. 2019, 370, 490-503. [CrossRef]

180. Khalil, M.A.; Hraběta, J.; Groh, T.; Procházka, P.; Doktorová, H.; Eckschlager, T. Valproic Acid Increases CD133 Positive Cells That Show Low Sensitivity to Cytostatics in Neuroblastoma. PLoS ONE 2016, 11, e0162916. [CrossRef]

181. Blaheta, R.A.; Michaelis, M.; Natsheh, I.; Hasenberg, C.; Weich, E.; Relja, B.; Jonas, D.; Doerr, H.W.; Cinatl, J. Valproic Acid Inhibits Adhesion of Vincristine- and Cisplatin-Resistant Neuroblastoma Tumour Cells to Endothelium. Br. J. Cancer 2007, 96, 1699-1706. [CrossRef]

182. DuBois, S.G.; Marachelian, A.; Fox, E.; Kudgus, R.A.; Reid, J.M.; Groshen, S.; Malvar, J.; Bagatell, R.; Wagner, L.; Maris, J.M.; et al. Phase I Study of the Aurora A Kinase Inhibitor Alisertib in Combination With Irinotecan and Temozolomide for Patients With Relapsed or Refractory Neuroblastoma: A NANT (New Approaches to Neuroblastoma Therapy) Trial. J. Clin. Oncol. 2016, 34, 1368-1375. [CrossRef]

183. Wang, J.; Jiang, J.; Chen, H.; Wang, L.; Guo, H.; Yang, L.; Xiao, D.; Qing, G.; Liu, H. FDA-Approved Drug Screen Identifies Proteasome as a Synthetic Lethal Target in MYC-Driven Neuroblastoma. Oncogene 2019, 38, 6737-6751. [CrossRef]

184. Kroesen, M.; Büll, C.; Gielen, P.R.; Brok, I.C.; Armandari, I.; Wassink, M.; Looman, M.W.G.; Boon, L.; den Brok, M.H.; Hoogerbrugge, P.M.; et al. Anti-GD2 MAb and Vorinostat Synergize in the Treatment of Neuroblastoma. Oncoimmunology 2016, 5, e1164919. [CrossRef]

185. Pinto, N.; DuBois, S.G.; Marachelian, A.; Diede, S.J.; Taraseviciute, A.; Glade Bender, J.L.; Tsao-Wei, D.; Groshen, S.G.; Reid, J.M.; Haas-Kogan, D.A.; et al. Phase I Study of Vorinostat in Combination with Isotretinoin in Patients with Refractory/Recurrent Neuroblastoma: A New Approaches to Neuroblastoma Therapy (NANT) Trial. Pediatr. Blood Cancer 2018, 65, e27023. [CrossRef]

186. Mueller, S.; Yang, X.; Sottero, T.L.; Gragg, A.; Prasad, G.; Polley, M.-Y.; Weiss, W.A.; Matthay, K.K.; Davidoff, A.M.; DuBois, S.G.; et al. Cooperation of the HDAC Inhibitor Vorinostat and Radiation in Metastatic Neuroblastoma: Efficacy and Underlying Mechanisms. Cancer Lett. 2011, 306, 223-229. [CrossRef]

187. DuBois, S.G.; Groshen, S.; Park, J.R.; Haas-Kogan, D.A.; Yang, X.; Geier, E.; Chen, E.; Giacomini, K.; Weiss, B.; Cohn, S.L.; et al. Phase I Study of Vorinostat as a Radiation Sensitizer with 131I-Metaiodobenzylguanidine (131I-MIBG) for Patients with Relapsed or Refractory Neuroblastoma. Clin. Cancer Res. 2015, 21, 2715-2721. [CrossRef]

188. Cortés, C.; Kozma, S.C.; Tauler, A.; Ambrosio, S. MYCN Concurrence with SAHA-Induced Cell Death in Human Neuroblastoma Cells. Cell. Oncol. 2015, 38, 341-352. [CrossRef]

189. Müller, I.; Larsson, K.; Frenzel, A.; Oliynyk, G.; Zirath, H.; Prochownik, E.V.; Westwood, N.J.; Henriksson, M.A. Targeting of the MYCN Protein with Small Molecule C-MYC Inhibitors. PLoS ONE 2014, 9, e97285. [CrossRef]

190. Wang, H.; Teriete, P.; Hu, A.; Raveendra-Panickar, D.; Pendelton, K.; Lazo, J.S.; Eiseman, J.; Holien, T.; Misund, K.; Oliynyk, G.; et al. Direct Inhibition of C-Myc-Max Heterodimers by Celastrol and Celastrol-Inspired Triterpenoids. Oncotarget 2015, 6, 32380-32395. [CrossRef] [PubMed] 
191. Lu, X.; Vogt, P.K.; Boger, D.L.; Lunec, J. Disruption of the MYC Transcriptional Function by a Small-Molecule Antagonist of MYC/MAX Dimerization. Oncol. Rep. 2008, 19, 825-830. [CrossRef] [PubMed]

192. Han, H.; Jain, A.D.; Truica, M.I.; Izquierdo-Ferrer, J.; Anker, J.F.; Lysy, B.; Sagar, V.; Luan, Y.; Chalmers, Z.R.; Unno, K.; et al. Small-Molecule MYC Inhibitors Suppress Tumor Growth and Enhance Immunotherapy. Cancer Cell 2019, 36, 483-497.e15. [CrossRef]

193. Massó-Vallés, D.; Beaulieu, M.-E.; Soucek, L. MYC, MYCL, and MYCN as Therapeutic Targets in Lung Cancer. Expert Opin. Ther. Targets 2020, 24, 101-114. [CrossRef]

194. Fiorentino, F.P.; Tokgün, E.; Solé-Sánchez, S.; Giampaolo, S.; Tokgün, O.; Jauset, T.; Kohno, T.; Perucho, M.; Soucek, L.; Yokota, J. Growth Suppression by MYC Inhibition in Small Cell Lung Cancer Cells with TP53 and RB1 Inactivation. Oncotarget 2016, 7, 31014-31028. [CrossRef]

195. Wang, C.; Zhang, J.; Yin, J.; Gan, Y.; Xu, S.; Gu, Y.; Huang, W. Alternative Approaches to Target Myc for Cancer Treatment. Signal Transduct. Target. Ther. 2021, 6, 117. [CrossRef]

196. Gamble, L.D.; Purgato, S.; Murray, J.; Xiao, L.; Yu, D.M.T.; Hanssen, K.M.; Giorgi, F.M.; Carter, D.R.; Gifford, A.J.; Valli, E.; et al. Inhibition of Polyamine Synthesis and Uptake Reduces Tumor Progression and Prolongs Survival in Mouse Models of Neuroblastoma. Sci. Transl. Med. 2019, 11, eaau1099. [CrossRef]

197. Sholler, G.L.S.; Ferguson, W.; Bergendahl, G.; Bond, J.P.; Neville, K.; Eslin, D.; Brown, V.; Roberts, W.; Wada, R.K.; Oesterheld, J.; et al. Maintenance DFMO Increases Survival in High Risk Neuroblastoma. Sci. Rep. 2018, 8, 14445. [CrossRef]

198. Bassiri, H.; Benavides, A.; Haber, M.; Gilmour, S.K.; Norris, M.D.; Hogarty, M.D. Translational Development of Difluoromethylornithine (DFMO) for the Treatment of Neuroblastoma. Transl. Pediatr. 2015, 4, 226-238. [CrossRef]

199. Evageliou, N.F.; Haber, M.; Vu, A.; Laetsch, T.W.; Murray, J.; Gamble, L.D.; Cheng, N.C.; Liu, K.; Reese, M.; Corrigan, K.A.; et al. Polyamine Antagonist Therapies Inhibit Neuroblastoma Initiation and Progression. Clin. Cancer Res. 2016, 22, $4391-4404$. [CrossRef]

200. Schultz, C.R.; Geerts, D.; Mooney, M.; El-Khawaja, R.; Koster, J.; Bachmann, A.S. Synergistic Drug Combination GC7/DFMO Suppresses Hypusine/Spermidine-Dependent EIF5A Activation and Induces Apoptotic Cell Death in Neuroblastoma. Biochem. J. 2018, 475, 531-545. [CrossRef]

201. Rounbehler, R.J.; Li, W.; Hall, M.A.; Yang, C.; Fallahi, M.; Cleveland, J.L. Targeting Ornithine Decarboxylase Impairs Development of MYCN-Amplified Neuroblastoma. Cancer Res. 2009, 69, 547-553. [CrossRef]

202. Samal, K.; Zhao, P.; Kendzicky, A.; Yco, L.P.; McClung, H.; Gerner, E.; Burns, M.; Bachmann, A.S.; Sholler, G. AMXT-1501, a Novel Polyamine Transport Inhibitor, Synergizes with DFMO in Inhibiting Neuroblastoma Cell Proliferation by Targeting Both Ornithine Decarboxylase and Polyamine Transport. Int. J. Cancer 2013, 133, 1323-1333. [CrossRef]

203. Koach, J.; Holien, J.K.; Massudi, H.; Carter, D.R.; Ciampa, O.C.; Herath, M.; Lim, T.; Seneviratne, J.A.; Milazzo, G.; Murray, J.E.; et al. Drugging MYCN Oncogenic Signaling through the MYCN-PA2G4 Binding Interface. Cancer Res. 2019, 79, 5652-5667. [CrossRef]

204. Xu, D.-Q.; Toyoda, H.; Yuan, X.-J.; Qi, L.; Chelakkot, V.S.; Morimoto, M.; Hanaki, R.; Kihira, K.; Hori, H.; Komada, Y.; et al. Anti-Tumor Effect of AZD8055 against Neuroblastoma Cells in Vitro and in Vivo. Exp. Cell Res. 2018, 365, 177-184. [CrossRef]

205. Xu, D.-Q.; Toyoda, H.; Qi, L.; Morimoto, M.; Hanaki, R.; Iwamoto, S.; Komada, Y.; Hirayama, M. Induction of MEK/ERK Activity by AZD8055 Confers Acquired Resistance in Neuroblastoma. Biochem. Biophys. Res. Commun. 2018, 499, 425-432. [CrossRef] [PubMed]

206. Qi, L.; Toyoda, H.; Xu, D.-Q.; Zhou, Y.; Sakurai, N.; Amano, K.; Kihira, K.; Hori, H.; Azuma, E.; Komada, Y. PDK1-MTOR Signaling Pathway Inhibitors Reduce Cell Proliferation in MK2206 Resistant Neuroblastoma Cells. Cancer Cell Int. $2015,15,91$. [CrossRef] [PubMed]

207. Kiessling, M.K.; Curioni-Fontecedro, A.; Samaras, P.; Lang, S.; Scharl, M.; Aguzzi, A.; Oldrige, D.A.; Maris, J.M.; Rogler, G. Targeting the MTOR Complex by Everolimus in NRAS Mutant Neuroblastoma. PLoS ONE 2016, 11, e0147682. [CrossRef] [PubMed]

208. Gu, X.; Hua, Z.; Dong, Y.; Zhan, Y.; Zhang, X.; Tian, W.; Liu, Z.; Thiele, C.J.; Li, Z. Proteome and Acetylome Analysis Identifies Novel Pathways and Targets Regulated by Perifosine in Neuroblastoma. Sci. Rep. 2017, 7, 42062. [CrossRef] [PubMed]

209. Matsumoto, K.; Shichino, H.; Kawamoto, H.; Kosaka, Y.; Chin, M.; Kato, K.; Mugishima, H. Phase I Study of Perifosine Monotherapy in Patients with Recurrent or Refractory Neuroblastoma. Pediatr. Blood Cancer 2017, 64, e26623. [CrossRef]

210. Sun, W.; Modak, S. Emerging Treatment Options for the Treatment of Neuroblastoma: Potential Role of Perifosine. Onco TargetsTher. 2012, 5, 21-29. [CrossRef]

211. Qi, L.; Toyoda, H.; Shankar, V.; Sakurai, N.; Amano, K.; Kihira, K.; Iwasa, T.; Deguchi, T.; Hori, H.; Azuma, E.; et al. Heterogeneity of Neuroblastoma Cell Lines in Insulin-like Growth Factor 1 Receptor/Akt Pathway-Mediated Cell Proliferative Responses. Cancer Sci. 2013, 104, 1162-1171. [CrossRef]

212. Erdreich-Epstein, A.; Singh, A.R.; Joshi, S.; Vega, F.M.; Guo, P.; Xu, J.; Groshen, S.; Ye, W.; Millard, M.; Campan, M.; et al. Association of High Microvessel Av $\beta 3$ and Low PTEN with Poor Outcome in Stage 3 Neuroblastoma: Rationale for Using First in Class Dual PI3K/BRD4 Inhibitor, SF1126. Oncotarget 2017, 8, 52193-52210. [CrossRef]

213. Radic-Sarikas, B.; Halasz, M.; Huber, K.V.M.; Winter, G.E.; Tsafou, K.P.; Papamarkou, T.; Brunak, S.; Kolch, W.; Superti-Furga, G. Lapatinib Potentiates Cytotoxicity of YM155 in Neuroblastoma via Inhibition of the ABCB1 Efflux Transporter. Sci. Rep. 2017, 7, 3091. [CrossRef] 
214. Whittle, S.B.; Patel, K.; Zhang, L.; Woodfield, S.E.; Du, M.; Smith, V.; Zage, P.E. The Novel Kinase Inhibitor Ponatinib Is an Effective Anti-Angiogenic Agent against Neuroblastoma. Investig. New Drugs 2016, 34, 685-692. [CrossRef]

215. Li, H.; Wang, Y.; Chen, Z.; Lu, J.; Pan, J.; Yu, Y.; Zhao, Y.; Zhang, H.; Hu, T.; Liu, Q.; et al. Novel Multiple Tyrosine Kinase Inhibitor Ponatinib Inhibits BFGF-Activated Signaling in Neuroblastoma Cells and Suppresses Neuroblastoma Growth in Vivo. Oncotarget 2017, 8, 5874-5884. [CrossRef]

216. Sidarovich, V.; De Mariano, M.; Aveic, S.; Pancher, M.; Adami, V.; Gatto, P.; Pizzini, S.; Pasini, L.; Croce, M.; Parodi, F.; et al. A High-Content Screening of Anticancer Compounds Suggests the Multiple Tyrosine Kinase Inhibitor Ponatinib for Repurposing in Neuroblastoma Therapy. Mol. Cancer Ther. 2018, 17, 1405-1415. [CrossRef]

217. Kalkat, M.; Resetca, D.; Lourenco, C.; Chan, P.-K.; Wei, Y.; Shiah, Y.-J.; Vitkin, N.; Tong, Y.; Sunnerhagen, M.; Done, S.J.; et al. MYC Protein Interactome Profiling Reveals Functionally Distinct Regions That Cooperate to Drive Tumorigenesis. Mol. Cell 2018, 72, 836-848.e7. [CrossRef]

218. Baluapuri, A.; Wolf, E.; Eilers, M. Target Gene-Independent Functions of MYC Oncoproteins. Nat. Rev. Mol. Cell Biol. 2020, 21, 255-267. [CrossRef]

219. Meyer, N.; Penn, L.Z. Reflecting on 25 Years with MYC. Nat. Rev. Cancer 2008, 8, 976-990. [CrossRef]

220. Ferrucci, F.; Ciaccio, R.; Monticelli, S.; Pigini, P.; di Giacomo, S.; Purgato, S.; Erriquez, D.; Bernardoni, R.; Norris, M.; Haber, M.; et al. MAX to MYCN Intracellular Ratio Drives the Aggressive Phenotype and Clinical Outcome of High Risk Neuroblastoma. Biochim. Biophys. Acta Gene Regul. Mech. 2018, 1861, 235-245. [CrossRef]

221. Berg, T.; Cohen, S.B.; Desharnais, J.; Sonderegger, C.; Maslyar, D.J.; Goldberg, J.; Boger, D.L.; Vogt, P.K. Small-Molecule Antagonists of Myc/Max Dimerization Inhibit Myc-Induced Transformation of Chicken Embryo Fibroblasts. Proc. Natl. Acad. Sci. USA 2002, 99, 3830-3835. [CrossRef]

222. Yin, X.; Giap, C.; Lazo, J.S.; Prochownik, E.V. Low Molecular Weight Inhibitors of Myc-Max Interaction and Function. Oncogene 2003, 22, 6151-6159. [CrossRef] [PubMed]

223. Heller, G.T.; Aprile, F.A.; Bonomi, M.; Camilloni, C.; De Simone, A.; Vendruscolo, M. Sequence Specificity in the Entropy-Driven Binding of a Small Molecule and a Disordered Peptide. J. Mol. Biol. 2017, 429, 2772-2779. [CrossRef]

224. Massó-Vallés, D.; Soucek, L. Blocking Myc to Treat Cancer: Reflecting on Two Decades of Omomyc. Cells 2020, 9, 883. [CrossRef]

225. Farrell, A.S.; Sears, R.C. MYC Degradation. Cold Spring Harb. Perspect. Med. 2014, 4, a014365. [CrossRef]

226. Gustafson, W.C.; Meyerowitz, J.G.; Nekritz, E.A.; Chen, J.; Benes, C.; Charron, E.; Simonds, E.F.; Seeger, R.; Matthay, K.K.; Hertz, N.T.; et al. Drugging MYCN through an Allosteric Transition in Aurora Kinase A. Cancer Cell 2014, 26, 414-427. [CrossRef]

227. Thomas, L.R.; Adams, C.M.; Fesik, S.W.; Eischen, C.M.; Tansey, W.P. Targeting MYC through WDR5. Mol. Cell. Oncol. 2020, 7, 1709388. [CrossRef] [PubMed]

228. Ackermann, S.; Goeser, F.; Schulte, J.H.; Schramm, A.; Ehemann, V.; Hero, B.; Eggert, A.; Berthold, F.; Fischer, M. Polo-like Kinase 1 Is a Therapeutic Target in High-Risk Neuroblastoma. Clin. Cancer Res. 2011, 17, 731-741. [CrossRef]

229. Tavana, O.; Li, D.; Dai, C.; Lopez, G.; Banerjee, D.; Kon, N.; Chen, C.; Califano, A.; Yamashiro, D.J.; Sun, H.; et al. HAUSP Deubiquitinates and Stabilizes N-Myc in Neuroblastoma. Nat. Med. 2016, 22, 1180-1186. [CrossRef]

230. Hogarty, M.D.; Norris, M.D.; Davis, K.; Liu, X.; Evageliou, N.F.; Hayes, C.S.; Pawel, B.; Guo, R.; Zhao, H.; Sekyere, E.; et al. ODC1 Is a Critical Determinant of MYCN Oncogenesis and a Therapeutic Target in Neuroblastoma. Cancer Res. 2008, 68, 9735-9745. [CrossRef]

231. Thomas, T.; Thomas, T.J. Polyamines in Cell Growth and Cell Death: Molecular Mechanisms and Therapeutic Applications. Cell Mol. Life Sci. 2001, 58, 244-258. [CrossRef]

232. Casero, R.A.; Marton, L.J. Targeting Polyamine Metabolism and Function in Cancer and Other Hyperproliferative Diseases. Nat. Rev. Drug Discov. 2007, 6, 373-390. [CrossRef] [PubMed]

233. Lewis, E.C.; Kraveka, J.M.; Ferguson, W.; Eslin, D.; Brown, V.I.; Bergendahl, G.; Roberts, W.; Wada, R.K.; Oesterheld, J.; Mitchell, D.; et al. A Subset Analysis of a Phase II Trial Evaluating the Use of DFMO as Maintenance Therapy for High-Risk Neuroblastoma. Int. J. Cancer 2020, 147, 3152-3159. [CrossRef] [PubMed]

234. Gamble, L.D.; Purgato, S.; Henderson, M.J.; Di Giacomo, S.; Russell, A.J.; Pigini, P.; Murray, J.; Valli, E.; Milazzo, G.; Giorgi, F.M.; et al. A G316A Polymorphism in the Ornithine Decarboxylase Gene Promoter Modulates MYCN-Driven Childhood Neuroblastoma. Cancers 2021, 13, 1807. [CrossRef]

235. Bouchard, C.; Dittrich, O.; Kiermaier, A.; Dohmann, K.; Menkel, A.; Eilers, M.; Lüscher, B. Regulation of Cyclin D2 Gene Expression by the Myc/Max/Mad Network: Myc-Dependent TRRAP Recruitment and Histone Acetylation at the Cyclin D2 Promoter. Genes Dev. 2001, 15, 2042-2047. [CrossRef]

236. Woo, C.-W.; Tan, F.; Cassano, H.; Lee, J.; Lee, K.C.; Thiele, C.J. Use of RNA Interference to Elucidate the Effect of MYCN on Cell Cycle in Neuroblastoma. Pediatr. Blood Cancer 2008, 50, 208-212. [CrossRef]

237. Vanhaesebroeck, B.; Stephens, L.; Hawkins, P. PI3K Signalling: The Path to Discovery and Understanding. Nat. Rev. Mol. Cell Biol. 2012, 13, 195-203. [CrossRef]

238. Opel, D.; Poremba, C.; Simon, T.; Debatin, K.-M.; Fulda, S. Activation of Akt Predicts Poor Outcome in Neuroblastoma. Cancer Res. 2007, 67, 735-745. [CrossRef]

239. Loh, A.H.P.; Brennan, R.C.; Lang, W.H.; Hickey, R.J.; Malkas, L.H.; Sandoval, J.A. Dissecting the PI3K Signaling Axis in Pediatric Solid Tumors: Novel Targets for Clinical Integration. Front. Oncol. 2013, 3, 93. [CrossRef] 
240. Bold, R.J.; Kim, H.J.; Ishizuka, J.; Townsend, C.M.; Thompson, J.C. A Human Gastric Cancer Cell Line Possesses a Functional Receptor for Gastrin-Releasing Peptide. Cancer Investig. 1998, 16, 12-17. [CrossRef]

241. Chen, Y.; Takita, J.; Choi, Y.L.; Kato, M.; Ohira, M.; Sanada, M.; Wang, L.; Soda, M.; Kikuchi, A.; Igarashi, T.; et al. Oncogenic Mutations of ALK Kinase in Neuroblastoma. Nature 2008, 455, 971-974. [CrossRef]

242. Li, Z.; Zhang, Y.; Tong, Y.; Tong, J.; Thiele, C.J. Trk Inhibitor Attenuates the BDNF/TrkB-Induced Protection of Neuroblastoma Cells from Etoposide in Vitro and in Vivo. Cancer Biol. Ther. 2015, 16, 477-483. [CrossRef]

243. Liu, X.; Turbyville, T.; Fritz, A.; Whitesell, L. Inhibition of Insulin-like Growth Factor I Receptor Expression in Neuroblastoma Cells Induces the Regression of Established Tumors in Mice. Cancer Res. 1998, 58, 5432-5438. [CrossRef]

244. Ho, R.; Minturn, J.E.; Hishiki, T.; Zhao, H.; Wang, Q.; Cnaan, A.; Maris, J.; Evans, A.E.; Brodeur, G.M. Proliferation of Human Neuroblastomas Mediated by the Epidermal Growth Factor Receptor. Cancer Res. 2005, 65, 9868-9875. [CrossRef] [PubMed]

245. Raica, M.; Cimpean, A.M. Platelet-Derived Growth Factor (PDGF)/PDGF Receptors (PDGFR) Axis as Target for Antitumor and Antiangiogenic Therapy. Pharmaceuticals 2010, 3, 572-599. [CrossRef] [PubMed]

246. Kang, J.; Rychahou, P.G.; Ishola, T.A.; Mourot, J.M.; Evers, B.M.; Chung, D.H. N-Myc Is a Novel Regulator of PI3K-Mediated VEGF Expression in Neuroblastoma. Oncogene 2008, 27, 3999-4007. [CrossRef] [PubMed]

247. Fletcher, J.I.; Ziegler, D.S.; Trahair, T.N.; Marshall, G.M.; Haber, M.; Norris, M.D. Too Many Targets, Not Enough Patients: Rethinking Neuroblastoma Clinical Trials. Nat. Rev. Cancer 2018, 18, 389-400. [CrossRef]

248. Mossé, Y.P.; Lim, M.S.; Voss, S.D.; Wilner, K.; Ruffner, K.; Laliberte, J.; Rolland, D.; Balis, F.M.; Maris, J.M.; Weigel, B.J.; et al Safety and Activity of Crizotinib for Paediatric Patients with Refractory Solid Tumours or Anaplastic Large-Cell Lymphoma: A Children's Oncology Group Phase 1 Consortium Study. Lancet Oncol. 2013, 14, 472-480. [CrossRef]

249. Domingo-Fernandez, R.; Watters, K.; Piskareva, O.; Stallings, R.L.; Bray, I. The Role of Genetic and Epigenetic Alterations in Neuroblastoma Disease Pathogenesis. Pediatr. Surg. Int. 2013, 29, 101-119. [CrossRef]

250. Hassell, K.N. Histone Deacetylases and Their Inhibitors in Cancer Epigenetics. Diseases 2019, 7, 57. [CrossRef]

251. Rocchi, P.; Tonelli, R.; Camerin, C.; Purgato, S.; Fronza, R.; Bianucci, F.; Guerra, F.; Pession, A.; Ferreri, A.M. P21Waf1/Cip1 Is a Common Target Induced by Short-Chain Fatty Acid HDAC Inhibitors (Valproic Acid, Tributyrin and Sodium Butyrate) in Neuroblastoma Cells. Oncol. Rep. 2005, 13, 1139-1144. [CrossRef]

252. Stockhausen, M.-T.; Sjölund, J.; Manetopoulos, C.; Axelson, H. Effects of the Histone Deacetylase Inhibitor Valproic Acid on Notch Signalling in Human Neuroblastoma Cells. Br. J. Cancer 2005, 92, 751-759. [CrossRef]

253. Cerna, T.; Hrabeta, J.; Eckschlager, T.; Frei, E.; Schmeiser, H.H.; Arlt, V.M.; Stiborová, M. The Histone Deacetylase Inhibitor Valproic Acid Exerts a Synergistic Cytotoxicity with the DNA-Damaging Drug Ellipticine in Neuroblastoma Cells. Int. J. Mol. Sci. 2018, 19, 164. [CrossRef]

254. Yang, Q.; Tian, Y.; Liu, S.; Zeine, R.; Chlenski, A.; Salwen, H.R.; Henkin, J.; Cohn, S.L. Thrombospondin-1 Peptide ABT-510 Combined with Valproic Acid Is an Effective Antiangiogenesis Strategy in Neuroblastoma. Cancer Res. 2007, 67, 1716-1724. [CrossRef]

255. Groh, T.; Hrabeta, J.; Poljakova, J.; Eckschlager, T.; Stiborova, M. Impact of Histone Deacetylase Inhibitor Valproic Acid on the Anticancer Effect of Etoposide on Neuroblastoma Cells. Neuro Endocrinol. Lett. 2012, 33 (Suppl. S3), 16-24.

256. Groh, T.; Hrabeta, J.; Khalil, M.A.; Doktorova, H.; Eckschlager, T.; Stiborova, M. The Synergistic Effects of DNA-Damaging Drugs Cisplatin and Etoposide with a Histone Deacetylase Inhibitor Valproate in High-Risk Neuroblastoma Cells. Int. J. Oncol. 2015, 47, 343-352. [CrossRef]

257. De los Santos, M.; Zambrano, A.; Aranda, A. Combined Effects of Retinoic Acid and Histone Deacetylase Inhibitors on Human Neuroblastoma SH-SY5Y Cells. Mol. Cancer Ther. 2007, 6, 1425-1432. [CrossRef]

258. Mühlethaler-Mottet, A.; Meier, R.; Flahaut, M.; Bourloud, K.B.; Nardou, K.; Joseph, J.-M.; Gross, N. Complex Molecular Mechanisms Cooperate to Mediate Histone Deacetylase Inhibitors Anti-Tumour Activity in Neuroblastoma Cells. Mol. Cancer 2008, 7, 55. [CrossRef]

259. van den Bijgaart, R.J.E.; Kroesen, M.; Brok, I.C.; Reijnen, D.; Wassink, M.; Boon, L.; Hoogerbrugge, P.M.; Adema, G.J. Anti-GD2 Antibody and Vorinostat Immunocombination Therapy Is Highly Effective in an Aggressive Orthotopic Neuroblastoma Model. Oncoimmunology 2020, 9, 1817653. [CrossRef]

260. Cheung, B.B.; Tan, O.; Koach, J.; Liu, B.; Shum, M.S.Y.; Carter, D.R.; Sutton, S.; Po'uha, S.T.; Chesler, L.; Haber, M.; et al. Thymosin-B4 Is a Determinant of Drug Sensitivity for Fenretinide and Vorinostat Combination Therapy in Neuroblastoma. Mol. Oncol. 2015, 9, 1484-1500. [CrossRef]

261. Huang, J.-M.; Sheard, M.A.; Ji, L.; Sposto, R.; Keshelava, N. Combination of Vorinostat and Flavopiridol Is Selectively Cytotoxic to Multidrug-Resistant Neuroblastoma Cell Lines with Mutant TP53. Mol. Cancer Ther. 2010, 9, 3289-3301. [CrossRef]

262. Hagiwara, K.; Tokunaga, T.; Iida, H.; Nagai, H. Combined Inhibition of ALK and HDAC Induces Synergistic Cytotoxicity in Neuroblastoma Cell Lines. Anticancer Res. 2019, 39, 3579-3584. [CrossRef] [PubMed]

263. Sanchez, G.J.; Richmond, P.A.; Bunker, E.N.; Karman, S.S.; Azofeifa, J.; Garnett, A.T.; Xu, Q.; Wheeler, G.E.; Toomey, C.M.; Zhang, Q.; et al. Genome-Wide Dose-Dependent Inhibition of Histone Deacetylases Studies Reveal Their Roles in Enhancer Remodeling and Suppression of Oncogenic Super-Enhancers. Nucleic Acids Res. 2018, 46, 1756-1776. [CrossRef] [PubMed]

264. Blavier, L.; Yang, R.-M.; DeClerck, Y.A. The Tumor Microenvironment in Neuroblastoma: New Players, New Mechanisms of Interaction and New Perspectives. Cancers 2020, 12, 2912. [CrossRef] [PubMed] 
265. Layer, J.P.; Kronmüller, M.T.; Quast, T.; van den Boorn-Konijnenberg, D.; Effern, M.; Hinze, D.; Althoff, K.; Schramm, A.; Westermann, F.; Peifer, M.; et al. Amplification of N-Myc Is Associated with a T-Cell-Poor Microenvironment in Metastatic Neuroblastoma Restraining Interferon Pathway Activity and Chemokine Expression. Oncoimmunology 2017, 6, e1320626. [CrossRef]

266. Zhong, X.; Zhang, Y.; Wang, L.; Zhang, H.; Liu, H.; Liu, Y. Cellular Components in Tumor Microenvironment of Neuroblastoma and the Prognostic Value. PeerJ 2019, 7, e8017. [CrossRef]

267. Joshi, S. Targeting the Tumor Microenvironment in Neuroblastoma: Recent Advances and Future Directions. Cancers 2020, 12, 2057. [CrossRef]

268. Nazha, B.; Inal, C.; Owonikoko, T.K. Disialoganglioside GD2 Expression in Solid Tumors and Role as a Target for Cancer Therapy. Front. Oncol. 2020, 10, 1000. [CrossRef]

269. Wu, Z.L.; Schwartz, E.; Seeger, R.; Ladisch, S. Expression of GD2 Ganglioside by Untreated Primary Human Neuroblastomas. Cancer Res. 1986, 46, 440-443.

270. Schengrund, C.L.; Shochat, S.J. Gangliosides in Neuroblastomas. Neurochem. Pathol. 1988, 8, 189-202. [CrossRef]

271. Sariola, H.; Terävä, H.; Rapola, J.; Saarinen, U.M. Cell-Surface Ganglioside GD2 in the Immunohistochemical Detection and Differential Diagnosis of Neuroblastoma. Am. J. Clin. Pathol. 1991, 96, 248-252. [CrossRef]

272. Dhillon, S. Dinutuximab: First Global Approval. Drugs 2015, 75, 923-927. [CrossRef]

273. Horwacik, I.; Golik, P.; Grudnik, P.; Kolinski, M.; Zdzalik, M.; Rokita, H.; Dubin, G. Structural Basis of GD2 Ganglioside and Mimetic Peptide Recognition by 14G2a Antibody. Mol. Cell Proteom. 2015, 14, 2577-2590. [CrossRef]

274. Schumacher-Kuckelkorn, R.; Volland, R.; Gradehandt, A.; Hero, B.; Simon, T.; Berthold, F. Lack of Immunocytological GD2 Expression on Neuroblastoma Cells in Bone Marrow at Diagnosis, during Treatment, and at Recurrence. Pediatr. Blood Cancer 2017, 64, 46-56. [CrossRef]

275. Van den Bijgaart, R.J.E.; Kroesen, M.; Wassink, M.; Brok, I.C.; Kers-Rebel, E.D.; Boon, L.; Heise, T.; van Scherpenzeel, M.; Lefeber, D.J.; Boltje, T.J.; et al. Combined Sialic Acid and Histone Deacetylase (HDAC) Inhibitor Treatment up-Regulates the Neuroblastoma Antigen GD2. J. Biol. Chem. 2019, 294, 4437-4449. [CrossRef] 